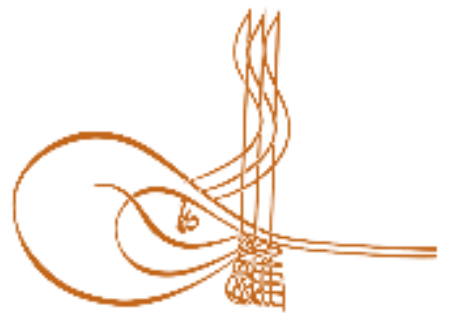

www.turkishstudies.net/turkishstudies
Turkish Studies

eISSN: $1308-2140$

Research Article / Araștırma Makalesi

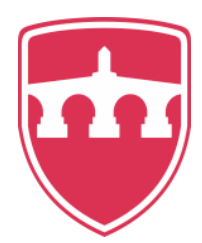

INTERNATIONAL

BALKAN

UNIVERSITY

Sponsored by IBU

\title{
Çanakkale’nin Tarihi Konakları
}

Historical Mansions of Çanakkale

Mesut Dündar*

\begin{abstract}
Kale-i Sultâniyye, has developed over time and become a seaport. Based on this development, large structures like mansions and pavilions in addition to houses were built in the city. However, most of these structures were destroyed in the fires, earthquakes and wars that occurred in the last centuries, and the remaining structures have been replaced by today's unidentified buildings due to the zoning pillage in recent years. Necip Pasha Mansion, Cevat Bey Mansion, Hasan Rami Pasha Mansion and Old Governor's Mansion, which were built in the late 19th and early 20th centuries, are some of the examples that could survive till today. In this study, it was aimed to examine the above-mentioned mansions, which have reached the present day, and to reveal their place and importance in both Çanakkale city architecture and Ottoman architecture. In line with this purpose, the relevant literature and archive reviews were firstly conducted, the structures were then examined on site and the mansions were introduced and evaluated in the light of the obtained data within a certain methodology. The mansions examined are in the form of detached houses with a garden, are two-storey over basement and have hippedgable roofs. The mansions reflecting the neoclassical style of the period attract attention with their facades connected to the road. The solid-void rate was taken into consideration in general facade design, volumetric outbuildings such as bay window and balcony together with doors and windows were included on the facades based on the planning. The structural elements on the facades such as corner plasters, pillars, floor moldings and cornices along with the doors, windows and outbuildings gave the facades movement. Traditional anteroom scheme was used in the floor plannings of the mansions forming a prism-type mass on the exterior. Although the interiors have been largely renovated, there are geometric decorations formed with slats on some of the ceilings. In general, the mansions reflecting the architectural and socio-cultural influences of the period are among the important works of both Çanakkale and Ottoman civil architecture.
\end{abstract}

Structured Abstract: Dating back to Kale-i Sultâniyye, the foundation of which was built by Fatih Sultan Mehmet, Çanakkale developed over time and became a port city; due to this development, large buildings such as regular houses and mansions including various residences were built in the city. However, a large part of them disappeared due to fire, earthquake, and wars, and the remaining structures are now being replaced with buildings without an identity due to reconstruction plans. Necip Pasha Mansion, Cevat Bey Mansion, Hasan Rami Pasha Mansion, and Eski Vali Mansion, which were built during the last period of the Ottoman Empire,

\footnotetext{
* Dr. Öğr. Üyesi, Çanakkale Onsekiz Mart Üniversitesi, Fen-Edebiyat Fakültesi, Sanat Tarihi Bölümü Asst. Prof. Dr., Canakkale Onsekiz Mart University, Faculty of Science and Letters Department of Art History ORCID 0000-0001-9934-5372

Checked by plagiarism software Published/Yayın: 29 February/Şubat 2020 CC BY-NC 4.0
} 
are a few examples that survived to date. In our study, it was aimed to contribute the literature in this field by examining these mansions, which do not have sufficient related research conducted and to reveal the place of these structures in Çanakkale city architecture and Ottoman residential architecture. In line with this purpose, firstly, literature and archive reviews were performed, then the works were examined on-site and with the data obtained, the mansions in question were introduced in detail and compared and evaluated.

The mansions, which form a rectangular prismatic mass overall, rise two floors on top of the basement far from the facade. Behind the buildings that have windows and doors leading to the street on which they are situated, there are courtyards with gardens; and in the gardens of Necip Paşa and Cevat Bey mansions, outbuildings such as baths, kitchens, and warehouses extending as parts of the mansions are included. It is understood that with the new lifestyle developing under the influence of western culture since the second half of the 19th century, similar Greek houses in the region affected the geometrical formations of the mansions and their outward designs, just as the other city mansions.

The mansions were generally built using stones and bricks in the West Anatolian coast, Islands and Marmara region. While the masonry stone walls were covered with plaster in Hasan Rami Pasha and Eski Vali Mansion, red brick was laid on the facade of Cevat Bey Mansion. This application, which is widespread in the West, especially in Italy, can be found in houses in nearby regions such as İzmir, Tekirdağ, and Istanbul, along with other structures in Çanakkale. Houses such as Necip Pasha Mansion, the lower floor of which is masonry and the upper floor of which is wooden, can be found in almost every region, especially in Western and Northern Anatolia, with some differences. Whether masonry or wood, traditional brick or mudbrick filled wood or plasterboard were used on all of the mansion's interior partition walls.

The neoclassical style of the west, which entered Turkish architecture from the 19th century and reflected on the houses towards the end of the century, was played an influential role in the facade designs of the mansions that form a rectangular prismal mass. In the mansions with rectangular facades, the floors are separated by profiled and flat moldings, the corners are indicated by doric plaster and columns. Facades facing the street of the facades, where a certain symmetry based on a simple geometry is sought, were kept more flashy than the others. The doors are placed at the center of the facades that carry a prestigious quality, and overhangs such as bay windows and balconies along with the windows are placed symmetrically concerning the door axis. While traditional bay windows are located at the entrance of Necip Pasha and Cevat Bey mansions, Hasan Rami and Eski Vali mansions have balconies. On the other facades of the mansions that draw attention with the front facades facing the road, similarly, the door and window openings, which are positioned according to the plan and spaces, depending on the occupancy-space ratio, are located as usual. On the facades of Hasan Rami Pasha and Eski Vali mansions, balconies as open overhangs, which are mostly found in Greek houses in the region and are common in Çanakkale can also be spotted. In addition to the structural elements such as neoclassical columns, plasters, caps, acanthus consoles, triangular pediments, arches and frieze, which give the facades their decorative features, vegetative decorations, such as vine trees, were placed under the balconies of the Eski Vali Mansion, again referring to the ancient period. One can encounter such neoclassical facade designs based on geometric symmetry, which include structural and vegetative decoration elements of the ancient period, especially in mansions and houses in the Aegean and Mediterranean and Marmara regions as well as Çanakkale.

Traditional plan schemes are used in the mansions that show western features with their mass and facade design. In Necip Paşa Mansion, Cevat Bey Mansion and Eski Vali Mansion, "inner-sofa?" plan was used and in the Hasan Rami Pasha Mansion, "middle-sofa" plan type was used. There is an entrance hall in front of the ground floor sofas of the Necip Paşa and Cevat Bey mansions that have inner-sofas, and the other end of the hall opens directly to the garden through a door. There is a room each for the four corners of the sofas, and the stairs that connect the floors, the toilet, and the bathroom are situated in between the rooms to the right and left. On upper floors where the same plan is repeated, sofas extending create overhangs over the entrance. Roughly, this inner-sofa plan scheme, consisting of three rectangular volumes with a parallel axis, also called "karnıyarı", has gained widespread attention since the 19th century and can be seen in almost every part of the Ottoman Empire. The medium-sofa plan scheme used in Hasan Rami Pasha Mansion is formed with a corner chamfer and two iwans. One of the iwans is arranged as an entrance and the other as a stairwell. There are middle spaces between each door and the corner rooms opening to the sofa. It is possible to come across many cities, especially Istanbul, having this type of middle-sofa plan based on Eski's central plan.

Turkish Studies, 15(1) 
Apart from Hasan Rami Pasha, the mansions maintain their general plan schemes; their interiors are greatly renovated and their original decoration and ornaments are not well-known. However, in old photographs, it can be seen that the ceilings generally had wastefill and that the entrance hall and sofa ceilings of Necip Paşa and Cevat Bey mansions geometrical compositions formed with profiled slats are located on the upper sofa ceiling of Eski Vali's Mansion. Besides, decorative wooden consoles, friezes and profiled moldings extending in between can also be seen in the ceiling skirts of Necip Pasha Mansion upper floor sofa. Geometric decorations created with profiled slats on the ceilings have been common in Turkish mansions and houses for a long time. Decorations in the form of neoclassical-effect decorative cantilever sequences and friezes seen on the ceiling skirts gained popularity as of the 19th century. And are mostly seen in mansions and houses on the western Anatolian shores, where non-Muslims are concentrated.

In conclusion, these garden mansions in Çanakkale, which seem to have been built by important people with a high-income, constitute important architectural works of the city and reveal the economic and social status of their owners and their cultural tendencies. It is possible to come across such mansions, which attract attention with the materials-techniques used, as well as their facades and plans, especially in the Aegean and Adalar and the Marmara region. Necip Pasha, Hasan Rami Pasha, Cevat Bey, and Eski Vali mansions, reflecting the architectural understanding and socio-cultural effects of the period and the region in general, are important in that they constitute the few examples of such structures built in the last period of the Ottoman Empire in Çanakkale.

Keywords: Dardanelles, Ottoman, Architecture, Mansion, House

Öz: Kuruluşu Kale-i Sultâniyye'nin inşasına dayanan Çanakkale, zamanla gelişerek bir liman kenti haline gelmiş bu gelişime bağlı olarak şehirde, birçok evle birlikte konak ve köşk gibi büyük yapılarda inşa edilmiştir. Ancak, son yüzyıllardaki yangın, deprem ve savaşlarda bunların büyük bir kısmı yok olmuş, kalanların yerini de son yıllardaki imar talanı nedeniyle günümüzün kimliksiz yapıları almaya başlamıştır. 19. yüzyıl sonları ile 20. yüzyıl başlarında inşa edilen Necip Paşa Konağı, Cevat Bey Konağı, Hasan Rami Paşa Konağı ve Eski Vali Konağı bunların günümüze ulaşabilen birkaç örneği oluşturmaktadır. Çalışmamızda, günümüze ulaşabilen yukarıdaki söz konusu konaklar incelenerek bunların hem Çanakkale kent mimarisi hem de Osmanlı mimarisindeki yeri ve önemi ortaya konması amaçlanmıştır. Bu amaç doğrultusunda, öncelikle konuyla ilgili literatür ve arşiv taramaları yapılmış, sonrasında yapılar yerinde incelenmiş ve elde edilen veriler 1şı ğında konaklar belirli bir metodoloji içersinde tanıtılarak değerlendirmeye tabi tutulmuştur. İncelenen konaklar, bahçeli müstakil yapılar şeklindeki olup, bodrum üzerine iki katlı ve kırma çatılıdırlar. Dönemin neoklasik üslubunu yansıtan konaklar yola bağlı ön cepheleri ile dikkat çekerler. Genel cephe tasarımında doluluk-boşluk oranına bağlı kalınmış, kapı ve pencereler ile birlikte cumba ve balkon gibi hacimsel çıkmalar, planlamaya bağlı olarak cephelerde yer almıştır. Cephelerdeki kapı, pencere ve çıkmalarla birlikte köşe plasterleri, sütunceler, kat silmeleri ve kornişler gibi yapısal ögeler cephelere hareket kazandırmıştır. Dışta prizmal bir kütle teşkil eden konakların kat planlarında geleneksel iç ve orta sofalı şemalar kullanılmıştır. İç mekânlar büyük oranda yenilenmekle birlikte, tavanların bazılarında çıtalarla oluşturulan geometrik süslemeler bulunmaktadır. Genel itibariyle, dönemin mimari ve sosyo-kültürel etkilerini yansıtan konaklar hem Çanakkale hem de Osmanlı sivil mimarisinin önemli eserlerini teşkil etmektedirler.

Anahtar Kelimeler: Çanakkale, Osmanlı, Mimari, Konak, Ev

\section{Giriş}

Çanakkale, iklimi ve coğrafi zenginlikleriyle ilkçağlardan beri yerleşimlere sahne olmuş ve çeşitli mitolojik öykülere konu edilmiştir. Uzun tarihi süreç içersinde savaşlar, yangınlar, depremler ve coğrafi etkenlere bağlı olarak Truva, Dardanos gibi antik şehirler terk edilirken bugünkü kent merkezi yeni yerleşim yeri olarak ortaya çıkmıştır (Tuncel, 1993:197). Yeni kent, Fatih Sultan Mehmed'in boğazın güvenliğini sağlamak için inşa ettirdiği Kale-i Sultaniye'nin (bkz., Acıoğlu, 2015) çevresinde gelişmeye başlar (Erten, 2012:401; Çoruhlu, 2008:3446). Zamanla çekim merkezi haline gelen kent Rum ve Ermeni yerleşimleriyle kuzey ve doğuya doğru genişler (Erten, 2012:405; Atabay, 2012:410-411). 1659 yılında Çanakkale'ye gelen (Çelik, 2012:140) Evliya Çelebi (1611- 
1682) seyahatnamesinde şehirden "Kal'anın cânib-i garbına ve şimâline meyyâl karîbce bir düz vâsi 'sahrada bâğlı ve bâğçeli gâyet ma'mûr kiremit örtülü tahtânî ve fevkânî iki bin adet evlerdir kim birbirlerinden vâsi'dir. Yolları zîk değildir. Pak şâhrâhları var" şeklinde bahseder (Kahraman vd., 2001:156). 18. yüzyıldan itibaren giderek bir ticaret merkezine dönüşen kent Yahudi ve Levanten yerleşimlerine de sahne olur (Erten, 2012:403). Yeni yerleşimlerle birlikte kentin sahil boyunca ve doğuya doğru genişleyerek büyümeye devam ettiği görülür. Çanakkale kent siluetinin oluşumunda, Türklerin yanı sıra gayrimüslimlerin ortaya koydukları ticaret yapıları ile birlikte konutlar önemli bir yer tutar. Bir yandan sahil boyunca bahçeli büyük konaklar inşa edilirken bir yandan da eskinin bahçeli geniş evlerinin yerini daha küçük konutlar ve dükkânlar almaya başlar. 19. yüzyılın sonlarında İmparatorluğun idari coğrafyası hakkında çalışmalar yapan Vital Cuinet (1894:747) şehirde 2040 adet evin bulunduğunu belirtirken, 1888 tarihli Karesi Vilayeti Salnamesi'nde Kale-i Sultaniye kazasında 3286 hanenin kayıtlı olduğu görülür (Kulu, 2008:1331). $\mathrm{Ne}$ var ki, tarihi süreç içerisinde oluşan bu kent dokusu ve birçok ev son yüzyıllardaki büyük yangınlar, depremler ve savaşlarla yok olmuştur (Atabay, 2012:419). 19. yüzyıl ile 20. yüzyılın başlarından günümüze ulaşabilen konutlar da özellikle 1950'lerden sonra hızlı bir tahribat sürecine girmiş ve günümüz mimarisinin kimliksiz yapıları bunların yerini almaya başlamıştır.

Çanakkale'nin günümüze ulaşabilen tarihi evlere bakıldığında bunların bağımsız konaklar veya sıraevler şeklinde oldukları görünür (Cantay, 1997:5). Çalışmamızda, genel olarak bahçeli büyük ve gösterişli evler şeklinde tanımlanan (Kuban, 1994:50; Orman, 2002:159; Hasol, 2012:273) ve sadece sayılı örnekleri kalan konaklar ele alınacaktır. Günümüzde Çanakkale Onsekiz Mart Üniversitesi'ne tahsis edilen Vitalis Konağı, Piri Reis Müzesi olarak hizmet veren Whittall Konağı, İngiliz Konağı olarak da bilinen "Necip Paşa Konăğ”, bir otel olarak kullanılan "Cevat Bey Konağı”, okul olarak kullanılan "Hasan Rami Paşa Konağı" ve Kültür Varlıklarını Koruma Bölge Kurulu Müdürlüğü binası olarak kullanılan "Eski Vali Konağı" bu sayılı örnekleri teşkil etmektedir. Bunlardan, Levantenler tarafından yaptırılan Vitalis ve Whittall konakları bir başka çalışmada (Dündar, 2019) ele alındığı için burada kapsam dışı bırakılmıştır. Bu çalışmada ele alınacak diğer dört konak hakkında ise doğrudan yapılmış bir araştırma bulunmamaktadır. Söz konusu konaklar ilk defa katalog mahiyetindeki bir yüksek lisans tezinde (Tolun, 2001) ele alınarak birer parağrafla tanıtılmıştır. Çanakkale Tarihi Kent Komisyonu tarafından hazırlanan (ed. İ. Erten, 1997) ve Gönül Cantay'ın metin yazarlığını yaptığı "Çanakkale Yapıları Tasarım Rehberi” adlı çalışmada, konutlardan bazıları çizimleri de verilerek diğer yapılarla birlikte genel olarak değerlendirilmiştir. Tülin Çoruhlu'nun "Çanakkale İlinde Sivil Mimari” adlı kısa makalesi (2008:3445-34-53) de bunun özeti şeklindeki benzer bir çalışmayı oluşturmaktadır. Bunların dışında, Çanakkale ile ilgili bazı kitaplarda (Tolun, 2012:49,61; Tombul, 2015:18,37,44) da konakların bazılarından birkaç cümle ile bahsedildiği görülür. Çalışmamızda, hem bu alandaki literatüre bir katkı sağlanması hem de söz konusu konakların Çanakkale kent mimarisi ile Osmanlı konut mimarisindeki yerlerinin ortaya konması amaçlanmıştır. Bu amaç doğrultusunda, öncelikle konuyla ilgili literatür ve arşiv taraması yapılmış, sonrasında eserler yerinde incelenmiş ve elde edilen verilerle birlikte söz konusu konaklar ayrıntılı biçimde tanıtılarak değerlendirilmeye tabi tutulmuş, sitil kritiği üzerinden bölgedeki dönemin benzer yapılarıyla karşılaştırılmıştır.

\section{Necip Paşa Konağı}

Cevatpaşa Mahallesi, Kayserili Ahmetpaşa Caddesi, No: 32/2'de (23 ada, 10 parsel) yer almaktadır. Daha çok İngiliz Konağı olarak bilinen yapının kesin inşa tarihi bilinmemektedir. Tapu kayıtlarından, konağın yer aldığı arazinin R.1300/M.1884 yıllarında vakıf tarlası olduğu, R.1311/M.1885 yılında da Bahr-i Sefid Boğazı Topçu Livası Necip Paşa ve eşi Hasibe Hanım tarafından burada bir ev yaptırmak için padişah iradesinin alındığı, R.1316/M.1900 arazi ve üzerindeki konağın Necip Paşa'nın varisleri tarafından İngiliz asıllı Ritali Grek'e satıldığı anlaşılmaktadır (Ç.K.V.K.B.K. Arşivi, Dosya No:17.00.3). Arazi sınırlarının belirtildiği satış tapusunda, "Fevkani: 5 oda ve bir sale ve tahtani 4 oda ve sofa ve mutfak ve bodrum ve bahçe ve 
hamam ve müştemilatı saireyi havi bir bab kargirhane yeri" şeklinde bir yapı kaydı bulunmaktadır. Söz konusu tapuda tanımlanan yapıyla bugünkü konağın uyuştuğu görülmektedir. Bu verilere göre konak, Necip Ahmed Paşa ve eşi tarafından padişahın iradesinin alındığı 1885 ile satışın gerçekleştiği 1900 yılları arasında yaptırılmış olmalıdır. Satıştan sonra veraset yoluyla uzun süre İngiliz ailenin elinde kalan konak 1976 yılında korunması gereken eski eser olarak tescil edilmiş, son varis Madam Hettie'nin 1977'deki ölümünden sonra Çanakkale belediyesince kamulaştırılarak Kültür Bakanlığına tahsis edilmiştir. Kültür Bakanlığı tarafindan 1988 yılında Devlet Güzel Sanatlar Galerisi Müdürlügüne tahsis edilen bina, 1990'larda restore edilmiş ve sanat galerisi olarak kullanıma açılmıştır. Konak 2010 yılında yeniden restore edilmiş, bu esnada dış cephedeki bozulan ahşap kaplamalar ve sıva ile birlikte iç mekânlardaki ahşap zemin döşemeleri ve tavan kaplamaları büyük oranda yenilenmiştir (Ç.K.V.K.B.K. Arşivi, Dosya No:17.00.3). Konak, günümüzde İl Kültür ve Turizm Müdürlüğü İdari Bürosu ve Devlet Güzel Sanatlar Galerisi olarak işlevini sürdürmektedir.

Bahçeli bir avlusu bulunan konak bodrum üzerine iki katlıdır (Resim 1 ve 2). Konağın güneydoğu köşesinde depo, mutfak ve hamam gibi tek katlı müştemilat yapıları yer alır. Ana binaya bağlanan bu yapılar aynı zamanda avlu cephesine katılmakta, bunların devamındaki ihata duvarları avluyu sinırlamaktadır.

Yola bağlı cephe gerisinde yükselen konağın bodrum katı taş, giriş katı tuğla, üst katı ise ahşaptır. Tek katlı müştemilat yapılarında da giriş katında olduğu gibi tuğla kullanılmıştır. Farklı malzemelerin kullanıldığı ana binada katlar profilli silmelerle birbirinden ayrılmıştır. Üstte, konsollarla desteklenen geniş bir saçak cepheleri dolanır. Saçağın gerisinde, çatıyı gizleyen ahşap parapet yükselir. Kırma çatı, alaturka kiremitle kaplıdır.

Neoklasik tarzdaki yapının caddeye açılan kuzey ön cephesi ile avluya bakan güney arka cephesi daha gösterişlidir (Resim 2). Ön cephenin önemi giriş katının taş kaplaması ile de vurgulanmıştır. Cephenin orta aksında kemerli bir niş şeklindeki hacimsel nitelikli kapı yer alır (Resim 3). Kilit taşı öne çıkarılan kemer yanlardaki impost başlıklı plasterlere biner. Akant yapraklarıyla bezeli başlıkların profilleri içeri doğru uzanarak gerideki kapı açıklı̆̆ının lentosuyla birleşir. Kapının profilli lentosu köşelerdeki impost başlıklı ayaklara biner. Kapı nişinin iki yanında birer pencere yer alır. Gerisindeki giriş holüne açılan bu kapı ve pencereler grubu dikdörtgen bir çerçeve içersine alınmıştır. Bunların iki yanında odalara açılan ikişer pencere bulunur (Resim 3). Dikdörtgen biçimli pencerelerin lento ve söveleri dişa taşırılarak belirtilmiştir. Pencerelerin konsollarla desteklenen denizlikleri altında panolara, üstlerinde akant yaprakları ve konsollardan oluşan süslemelere yer verilmiştir. Dekoratif konsolların üzerinde cephe boyunca profili bir silme uzanır. Giriş katındaki yan pencerelerin altında bodruma açılan yatay dikdörtgen şeklinde küçük pencereler bulunur. Giriş ve bodrum katı pencereleri işlemeli demir şebekelere sahiptir. Üst katta, giriş aksı üzerindeki orta kısım cumba şeklinde bir çıkma yapar. Cephede dikey bir bölünme yaratan cumba ile yan kanatların köşelerine ahşap sütunceler yerleştirilmiştir (Resim 3). Çokgen kesitli ince zarif sütunceler, yelpaze gibi açılan konsollu başlıklarla son bulur ve başlıklar en üstte saçağın devamı şeklinde çıkmalar yapar. Başlı̆̆ın alt hizasındaki ince bir silme cepheyi dolanır, bunun üzerinde saçağı destekleyen dekoratif ahşap konsollar sıralanır. Sütunce, saçak ve silmelerle sinırlandırılan cumba ve yan kanatların cephelerinde ikişer pencere, cumbanın yan yüzlerinde de birer pencere yer alır. İşlemeli pervazların çerçevelediği dikdörtgen formlu pencereler üçgen alınlıklara sahiptir (Resim 3). Cephede plastik bir etki yaratan bu üçgen alınlıkları köşelerdeki dekoratif konsollar destekler. Kepenkli pencerelerin ince profil silmeli denizlikleri alt köşelerinde stilize palmet şeklinde sarkıtlara yer verilmiştir. Cepheyi üstten sınırlayan geniş saçak ve onun gerisinde yükselen parapet diğer cephelere de uzanarak devam eder.

Ön cephedeki bu hareketlilik arka cepheye farklı şekilde yansıtılmıştır (Resim 2). Önde çıkma yapan cumbaya karşıllk arkada gömme balkona yer verilmiştir. Bir eyvan şeklinde tek cephe ile dışa açılan balkonu önde iki ahşap direk ve korkuluklar sınırlandırır. Gerisinde, sofa ile balkonu 
bağlayan kapı ve pencereler yer alır. Ortada hacimsel bir girinti oluşturan balkonun iki yanındaki odaların cephelerinde ikişer pencereye yer verilmiştir. Ön cephedekilerle benzer nitelikteki pencerelerin farklı olarak üçgen alınlıkları yoktur. Balkonun altında, giriş katına açılan bir kapı ile bunun iki yanında birer pencere yer alır. Kilit taşı öne çıkarılan basık kemerli kapıya çift kollu bir merdivenle ulaşılır. Orta akstaki bu üçlü açıklığın batısında iki, doğusunda da bir pencere bulunur. Doğudaki ikinci pencerenin yerini bitişiğindeki müştemilata açılan kapı almıştır. Dikdörtgen formlu pencerelerin taş lento ve söveleri taşırılarak vurgulanmıştır. Cephenin zemin seviyesinde bodruma açılan pencerelere yer verilmiştir. Üstekilerle aynı eksendeki bodrum pencereleri öndekilerden farklı olarak basık kemerlidirler. Batı taraftaki bodrum pencereleri arasında, taş merdivenle inilen basık kemerli bir kapıya yer verilerek bahçeden bodruma ulaşım sağlanmıştır.

Konağın yan cepheleri, ön ve arka cephelere göre daha masif ve yalındır (Resim 2). Herhangi bir çıkma veya girintisi bulunmayan yan cepheler kat ve saçak silmeleri nedeniyle yatay bir etki gösterir. Batı cephenin alt katında iki, üst katında ise dört pencere yer alır. Altta, cephenin iki ucuna yerleştirilen pencereler arasında küçük bir pencereye daha yer verilmiştir. Üst kattaki dört pencerenin ikisi ortaya diğer ikisi de kenarlara yerleştirilmiştir. Doğu cephenin üst katında ise belirli aralıklarda yerleştirilen üç pencere bulunmaktadır. Alt katın orta ekseninde bir kapı ile kuzey ucunda bir pencere yer alır. Basit görünüşlü bu tali kapı ile pencere arasında bodrum katından çıkan bir baca yükselir. Cephenin güney tarafina tek katlı müştemilat yapısı bitişir. Bunun hemen önünde bodruma açılan ikinci bir kapı yer alır. Her iki yan cephedeki pencerelerden kuzey uçtakiler ön cephedekilerle, diğerleri arka cephedekilerle aynıdır.

Dışta dikdörtgen bir kütle teşkil eden yapıda iç sofalı olarak adlandırılan (Eldem, 1954:25) plan şeması uygulanmıştır (Şekil 1). Zemin katta, sofanın ön tarafinda bir giriş holüne yer verilmiştir. Bunun iki yanında kapılarla hole açılan birer oda bulunur. Giriş holünden geçilen sofanın iki yanında sırasıyla merdivenkovaları ile odalar yer alır. Batıdaki merdivenkovası ile oda arasında bir de tuvalete yer verilmiştir. Sofaya açılan odalardan güneydoğu köşedeki bir kapıyla bitişiğindeki depoya, bir koridorla da mutfak ve hamama bağlanır. Salonun doğusundaki dairesel merdiven yalnızca üst kata bağlanırken, "U" şeklinde olan batıdaki bodrumdan çatıya kadar devam etmektedir. Paralel eksenli üç adet dikdörtgen hacimden gelişen orta sofalı plan şemasının uygulandığı üst katta, ortada sofanın öne doğru kaydırılmasıyla önde bir cumba arkada da bir gömme balkon elde edilmiştir. Yan birimlerin uçlarında sofaya açılan birer köşe odası, bunların arasında da merdivenkovaları yer alır. Her iki katta da mekânlar bağdadi duvarlarla birbirinden ayrılmıştır. Duvarları sıvalı olan mekânlardan giriş holü hariç hepsinin zemini ve tavanları ahşap kaplıdır. Giriş holü zemini mermer döşemelidir. Restorasyonlar sırasında, giriş holündeki özgün mermer döşemelerin korunduğu, diğerlerinin aslına uygun olarak yenilendiği anlaşılmaktadır (Ç.K.V.K.B.K. Arşivi, Dosya No:17.00.3).

Büyük oranda yenilenen yapı içerisinde fazla süslemeye rastlanılmaz. Yalnız, alt kat giriş holü ile üst kat sofasında, pasalı tavan uygulaması içerisinde çıtalarla teşkil olunan bazı geometrik kompozisyonlar görülür (Resim 4). Ayrıca, üst kat sofasının tavan eteklerinde ince profillerle yatay kuşaklar oluşturulmuş, burada bir diş frizine de yer verilmiştir. Bu profilli kuşaklarla diş frizini, tavana bağlanan dekoratif ahşap konsollar keser. Bunun dışında, Sofadan odalara açılan kapılar üzerinde de stilize palmetler şeklinde ahşap süslemelere yer verilmiştir.

Konağa güneydoğudan bitişen tek katlı müştemilat yapıları bahçeye doğru uzanarak yan yana sıralanır. Depo, tuvalet ve mutfak kısımları tekbir çatı altında toplanırken güney uçta yer alan hamam kubbeyle örtülmüştür. Dıştan sade bir görünüm arz eden yapılardan hamam haricindekilerde birer pencereye yer verilmiştir. Dikdörtgen çerçeveli pencerelerin taş söveleri hafif dışa taşkındır. Kuzey uçta yer alan depo bir kapı ile bitişiğindeki odaya açılmaktadır. Bahçeye doğru uzanan diğer kısımların önünde boydan boya uzanan bir koridora yer verilerek bunlar birbirlerine bağlanmış, bu koridor vasıtasıyla bahçeye ve güneydoğu köşedeki odaya açılmışlardır. Yenilenen iç mekânların 
tavanları ahşap pasalıdır. Hamamın kubbe geçişlerinde testere dişli ve düz silmeli dolgulara yer verilmiştir.

\section{Cevat Bey Konağı (Kervansaray Oteli)}

Kemalpaşa Mahallesi, Fetvane Sokak, No: 13'te (200 ada, 25 parsel) yer almaktadır. Girișin yanında R.1319/M.1903 tarihli bir tabela bulunan konağın belediye arşiv kayıtlarında, 1903 yılında Çanakkale kadısı Abdürrahim Efendi tarafından yaptırıldığı ve sonrasında oğlu Cevat Bey'e devredildiği yazmaktadır ${ }^{1}$. Bir yayında ise konağın 1919 yılında inşa edildiği ve inşaatında kullanılan tuğlaların İtalya'dan getirtildiği de ifade edilmektedir (Tolun, 2012:61) ${ }^{2}$. Konağın inşasına ilişkin söz konusu bilgiler tartışmalı olmakla birlikte, yapının kullanılan malzeme-teknik ve mimari üslubuna göre 20. yüzyılın başlarında inşa edildiği söylenebilir. Uzun yıllardır otel olarak kullanılan konak (Koçyiğit, 2017:132) 2005 yılında restore edilmiştir. Restorasyon sırasında odalardaki muhdes bölmelerin bazıları kaldırılmış, alt kat salon ve bazı odaların ahşap tavanları korunarak onarılmış, üst katın bozulan alçı tavanları ahşapla değiştirilmiş, zemin döşemeleri yenilenmiştir (Ç.K.V.K.B.K. Arşivi, Dosya No:17.00.15).

Konak, bir bodrum üzerine iki katlı olarak inşa edilmiştir (Resim 5). Köşe parselde yer alan konak, doğuda bitişik olup diğer üç cephe ile dışa açılmaktadır. Yola bağlı kuzey cephe gerisinde yükselen yapı kütlesinin arkasında bahçeli avlusu yer alır. Yüksek duvarlarla kuşatılan avluda mutfak ve depo gibi müştemilat birimleri ile bir kameriye ve kuyu bulunmaktadır. Güneybatı köşeden konağa bitişen müştemilatlar bir antre ile bahçeye açılır. Antreye sokaktan açılan bir kapı ile hem mutfağa hem de avluya dışarıdan ulaşım sağlanmıştır.

Yüksek bir taş subasman üzerine tuğla ile inşa edilen konakta kat silmeleri ve saçaklar ile bazı kapı, pencere ve taşıyıcılarda mermere yer verilmiştir. Dışa yansıtılan astarlı kırmızı tuğla ile birlikte kullanılan mermerler cephelere renkli bir görünün kazandırmıştır. Mermer saçak ve silmeler kat ayrımını belirgin kılarken bunlarla birlikte kullanılan konsol ve sarkıt gibi mermer öğeler de cephelere dekoratif bir zenginlik katmaktadır. Bir parapetle sonlanan cephelerin gerisinde kırma çatı yükselir.

Neoklasik üslubu yansıtan konağın yola bağlı ön cephesi, hacimsel nitelikli girişi ve üstteki cumba çıkmasıyla oldukça hareketli bir düzenleme gösterir (Resim 5). Ortada bir eyvan şeklinde girinti teşkil eden girişin gerisinde, hole açılan bir kapı ile iki pencere; yanlarında, köşe odalarına açılan birer pencere bulunur. Ortadaki kapı ile bunun iki yanındaki pencereler yarım daire kemerli, yanlardakiler ise düz lentoludur. Lento ve kemerler impost başl1klı sövelere biner. Ampir üslubunu yansıtan kapı ve pencerelerin kemer kilit taşları üzerindeki yıldız ve ay motifleri dikkat çeker. Kap1 kemer alınlığındaki stilize edilmiş güneş kursu şeklindeki demir şebeke yine aynı üslubun dilidir. Ortadaki kapıya çift kollu bir merdivenle ulaşılır. Kapı önündeki sahanlığın köşelerinde, yüksek mermer kaidelere binen ince demir sütunlar bulunur. Giriş ve cephe köşeleri mermer sütuncelerle belirtilmiştir. Köşe sütuncelerinin moresk tarzı başlıkları üzerinde bezemeli birer geçiş elamanı yer alır ve bunların üzerinde kat silmeleri uzanır (Resim 6). Bu profilli silmeler ve sütuncelerin çerçevelediği kanatlarda ikişer pencere bulunur (Resim 6). Dikdörtgen biçimli pencere açıklıklarını mermer lento ve söveler çerçeveler. Dişa taşıntılı pencereleri üstten profilli kornişler sınırlar. Pencereler işlemeli demir şebekelere sahiptir.

Üst katta, giriş üzerinde kütlesel bir çıkma yapan cumba cephede dikey bir bölünme meydana getirir. Cumbayı, alttaki sütunlara binen mermer konsollar destekler. 'S' kıvrımlı konsollar akant

\footnotetext{
${ }^{1}$ Söz konusu konakla ilgi bir semir ödevi hazırlayan T. Esen Öztürk, aralarında beşinci kuşak mirasçıların bulunduğu kişilerle yaptığ 1 röportajlarda bu bilgileri teyit etmektedir.

${ }^{2}$ Konağın inşasında kullanılan tuğlalarda “TRATELLİ ALLATINİ SALONICCO” damgası görülür. Yahudi İtalyan ailesi olan Allatini kardeşlerin daha çok Makedonya ve Yunanistan'da faaliyet gösteren aile şirketleri arasında, ürettikleri kızıl renkli tuğlalarla öne çıkan fabrikalarda bulunmaktadır. Sultan Abdülhamid de Selanik sürgünü sırasında (1909-1912) bu fabrikaların yanında yer alan C. Allatini’ye ait villada kalmıştır (bkz., Jewish, 2012:14-15).
} 
yapraklarıyla bezelidir (Resim 6). Cumba ve cephe köşelerinde tuğla örgülü plasterlere yer verilmiştir. Plasterler, üç sıra tuğlanın köşeli olarak dikine yerleştirilmesiyle oluşturulan yivli kaidelere binerler. Kaidenin en altındaki tuğla dizisi aynı şekilde bir bordür gibi tüm cepheyi dolanır. Plasterlerin üzerinde kompozit mermer başlıklar yer alır. Başlıkların altından uzanan profilli bir mermer silme cephede dolanır. Bunun altında tuğla ile teşkil olunan bir düz silme ile testere dişi şeklindeki bir kuşak bulunur. Bu köşe plasterleri ile bunların alt ve üstünden geçen silmeler cumba ve yan kanatların yüzeyinde çerçeveler oluşturur. Cumbanın ön yüzünde iki, yan yüzlerinde de daha dar olmak üzere birer pencereye yer verilmiştir. Öndeki ikili pencere yan kanatlarda da tekrarlanmıştır. Basık kemerli pencerelerin tuğla örgülü çerçeveleri hafif dışa taşkındır (Resim 6). Pencerelerin üzerinde tuğla ve mermer dizisinden oluşan kornişler bulunur. Kornişleri köşelerdeki dekoratif mermer konsollar destekler. Bu konsolların arasında ve pencere denizliğinin alt köşelerinde barok tarzı mermer süslemeler yer alır. Cepheyi üstten mermer saçak sınırlar. Köşelerdeki kompozit başlıklara binen profilli saçağı, belirli aralıklarla yerleştirilen mermer konsollar destekler (Resim 6). Saçağın gerisinde, çatıyı gizleyen tuğla parapet yükselir. Parapetin köşelerinde büyük süs vazolarına yer verilmiştir.

Konağın bir sokağa bakan batı yan cephesi, daha masif olmakla birlikte aynı şekildeki pencere, sütunce, plaster, saçak ve silmeler gibi yapısal ögelerle renkli bir görüntü sergiler (Resim 5). Yatay düzlemde uzanan cephede katlar, ön cephenin devamı şeklinde uzanan saçak ve silmelerle belirtilmiştir. Kat cepheleri, altta mermer sütunceler, üstte tuğla plasterlerle dikey olarak üçe bölünmüştür. Bu sütunce ve plasterler ile silmelerin çerçevelediği her bölümde birer pencereye yer verilmiştir. Aynı hizadaki pencerelerden aradakiler ortaya, yandakiler köşelere yakın olarak yerleştirilmiştir. Ön cephe saçak ve pencerelerinde görülen konsol ve sarkıt gibi dekoratif unsurlar burada da tekrarlanmıştır.

Bahçeye bakan arka cephe diğerlerine göre daha sadedir. Ortada, giriş aksının iki kat boyunca geri çekilmesiyle yanlarda kütlesel çıkmalar meydana getirilmiştir. Katları yalın düz silmeler ayırır. Giriş katın ortasında bir kapı ve iki yanındaki pencerelerden oluşan üçlü açıklığa yer verilmiştir. Düz mermer silmelerin çerçevelediği yarım daire kemerli kapı ve pencerelerin kilit taşları belirtilmiştir. Kütlesel bir çıkma yapan yan kanatların köşeleri plasterlerle vurgulanmıştır. Başlığ bulunmayan mermer plasterler kat silmesine kadar uzanırlar. Bu plaster ve silmelerin kuşattı̆g doğu kanadında iki pencere yer alır. Dikdörtgen biçimli pencerelerin mermer lento ve söveleri öne doğru çıkma yapar. Aynı pencere biçimi daha dar olarak girişe bakan yan yüzlerde de tekrarlanmıştır. Cephenin batı kanadına ise mutfak ve depodan oluşan tek katlı müştemilat bitişir. Silmelerle ayrılan üst katta mermer köşe plasterlerin yerini tuğla plasterler almıştır. İki yandan plasterlerin sınırladığ kanatların ön yüzleri ile ortadaki giriş aksı üzerinde ikişer, kanatların yan yüzlerinde de birer pencereye yer verilmiştir. Hafif basık kemerli pencerelerin tuğla örgülü lento ve söveleri dışa taşırılmıştır. Oldukça sade tutulan cepheyi üstten profilli ince bir mermer saçak sınırlar.

Dışta dikdörtgen prizmal bir kütle teşkil eden konağın içerisinde mekânlar iç sofalı plan şemasına göre düzenlenmiştir (Şekil 2). Yola bağlı cephe ortasında yer alan kapıdan önce giriş holüne, buradan da orta sofaya geçilmektedir. Bir kapı ile de arkadaki bahçeye açılan sofanın yanlarında, iki uçta birer oda ile bunlar arasındaki mekânlara yer verilmiştir. Bu ara mekânlardan doğudaki merdivenkovası batıdaki de tuvalet olarak değerlendirilmiştir. Odalar, bu merdiven ve tuvalet mekânları önündeki dar koridorlarla sofaya ve birbirlerine bağlanmış, böylelikle sofadan odaların içinin doğrudan görünmesi engellenerek bir mahremiyet sağlanmıştır. Doğuda yer alan "U" biçimli merdiven katlar arasındaki bağlantıyı sağlamaktadır. Kabaca, paralel eksenli üç dikdörtgen hacimle teşkil olunan plan üst katta da tekrarlanmış; burada, kesintisiz olarak uzanan orta sofa, önde dışa doğru taşarak cumba şeklinde bir çıkma meydana getirmiştir.

Onarımlar sırasında büyük oranda yenilen iç mekânların özgün dekorasyon ve süslemesi hakkında pek fazla bilgi yoktur. Eski resimlerde giriş holü ve sofaların ahşap tavalarında çıtalarla 
oluşturulan geometrik kompozisyonlara yer verildiği, diğer odaların pasalı ahşap tavanlı oldukları görülür (Resim 7). Süslemelerin görüldüğü giriş holü ile alt kat sofa tavanlarının aslına uygun olarak restore edildiği, diğer ahşap tavanların ise yenilendiği anlaşılmaktadır (Resim 8). Bunun dışında elden geçirilen ahşap merdivenin işlemeli korkuluk ve tırabzanları süslemeye dâhil edilebilir.

Arka bahçede, konağa bitişen tek katlı müştemilat yapısı kırma çatılı olup kapı ve pencerelerle avluya açılmaktadır. Müştemilata girişi sağlayan konak tarafındaki kapı düz lentoludur. Sade kapının mermer lento ve söveleri hafif dışa taşkındır. Yapı kütlesinin avluya bakan cephesi tuğla ile teşkil olunan düz silme ve köşe plasterlerle ile çerçevelenmiştir. Bir mutfak ve gerisindeki depodan oluşan yapıdaki bu iki birim cephede yüzeysel bir plaster ile belirtilmiştir. Önde mutfağa açılan altlı üstlü ikişer pencereye, geride depoya açılan tek pencereye yer verilmiştir. Dikdörtgen biçimli pencere açıklıklarından alttakiler taş, üsttekiler tuğla çerçevelidir ve bunlar hafif dışa taşırılarak belirtilmiştir. Diğer cepheleri tamamen masiftir. Müştemilatın planı işlevine göre şekillenmiştir. Öndeki antreye açılan kapıdan önce dikdörtgen planlı mutfağa girilir. İçinde bir ocağı bulunan mutfağın gerisinde aynı doğrultuda uzanan depo yer alır. Mutfağa göre daha yüksek kotta bulunan depoya ocak tarafındaki bir merdivenle ulaşılır. Aynı merdiven dönerek mutfağın üzerindeki asma kata da erişim sağlar. Asma kat antre üzerinden konağa kadar uzanır. Müştemilatın büyük oranda yenilenen iç mekânında herhangi bir süslemeye rastlanılmaz.

\section{Hasan Rami Paşa Konağı (18 Mart İlkokulu)}

Cevatpaşa Mahallesi'nde, İnönü Caddesi ile Hasan Paşa Sokağı'nın birleştiği köşede, No: 10'da (31 ada, 25 parsel) yer alır. Konağın, Bahr-i Sefid Filo komutanı Hasan Rami Paşa (18421923) (bkz., Türk Ansiklopedisi, 1971:24-25; Hasan Rami Paşa, 1324) tarafından yaptırıldığı ifade edilmektedir (Kalfa, 2008:34; Uygun, 2015:168). Bazı arşiv belgelerinden de Hasan Rami Paşa'nın Çanakkale'de birkaç evi ile bir hamam ve arabalığı bulunduğu anlaşılmaktadır ${ }^{3}$. Buna göre konak, kayıtlarda bahsi geçen ve aynı mevkide yer alan hamamla ${ }^{4}$ birlikte, Hasan Rami Paşa'nın Çanakkale'de görev yaptı̆ğ 1987 ile 1906 yılları arasında yaptırılmış olmalıdır. Konak, 1920'de Özel İdare'ye (İdare-i Hususi) bağışlanarak bir süre Çanakkale Memleket Hastanesi olarak kullanılmış, 1945 yılında 18 Mart İlköğretim Okuluna devredilmiştir (Kalfa, 2008:33-34; Aslan, 2006:28). Halen 18 Mart İlkokulu olarak hizmet vermekte olan yapı, 1998 yılında esaslı bir onarım geçirmiş, bu onarım sırasında içerideki ahşap kısımlar ve örtü betonarme olarak değiştirilmiş, mekânlar ihtiyaca göre yeniden planlanmıştır (Ç.K.V.K.B.K. Arşivi, Dosya No:17.0014).

Geniş bir bahçe içerisinde yer alan konak bodrum üzerine iki katlıdır (Resim 9 ve 10). İhata duvarıyla kuşatılan bahçenin cadde tarafında yer alan konağın arka bahçesine yeni okul binası inşa edilmiştir. Kesme taşla inşa edildiği anlaşılan konağın cepheleri sıvalı ve boyalıdır. Bodrumla birlikte dikdörtgen bir kütle şeklinde yükselen konakta katlar yatay silmelerle ayrılmıştır. Geniş bir saçakla sonlanan yapı kütlesini kırma çatı örtmektedir.

Döneminin neoklasik üslubunu yansıtan konağın caddeye bakan doğu ön cephesi diğerlerine göre daha gösterişlidir (Resim 10). Köşeler yivli plasterlerle belirtilmiştir. Bu plasterlere binen impost başlıkların profilli silmeleri ve diş frizi, bir korniş şeklinde cephe boyunca uzanarak katları ayırmaktadır. Üst katta kornişin yerini profilli bir silme alır. Silmenin hemen üstünde belirli aralıklarla yerleştirilen dekoratif taş konsollar bulunur. En üstte cepheyi sonlandıran geniş saçak onarımlar sırasında betonarmeye dönüştürülmüştür. Simetrik bir düzenleme gösteren cephenin orta aksında bir kapı ile bunun iki yanında küçük birer pencereye yer verilmiştir. Ortadaki bu kapı ve pencere grubunun iki yanında da simetrik ikişer pencere bulunur. Ortadaki kapıya çift kollu bir merdivenle ulaşılır. Düz lentolu kapı üçgen alınlıklıdır. Lentoyu köşelerdeki impost başlıklı söveler

\footnotetext{
${ }^{3}$ Devlet Arşivi, DH.MKT. / 2888-1 (H.13.07.1327); DH.MUI. / 85-50 (H.28.04.1328).

${ }^{4}$ Hastane Bayırı denilen mevkide, konağın yaklaşık 100 m. kuzeydoğusunda bulunan askeri hamam, Hasan Rami Paşa tarafından 1904 yılında yaptırılmıştır (bkz. Kalfa, 2008:34).
} 
taşır. Kapı açıklığını çerçeveleyen bu lento ve söveler ile alınlık dışa taşırılarak belirtilmiştir (Resim 11). Pencereler hafif basık kemerlidir. Profilli silmelerin çerçevelediği pencerelerin kemer kilit taşları öne çıkarılarak vurgulanmış, denizliklerin alt köşelerinde de dekoratif konsollara yer verilmiştir. Kapı ve iki yanındaki pencerelerden oluşan üçlü açıklığın üzerinde balkon çıkması yer alır. Herhangi bir desteği bulunmayan putrelli balkonu üç yönden dekoratif işlemeli demir korkuluklar kuşatır. Giriş katındaki kapı ve pencere düzenlemesi balkonun bulunduğu üst katta da aynen tekrarlanmıştır. Farklı olarak önündeki balkona açılan kapı da pencereler gibi basık kemerlidir. Bodrum katında, merdiven sahanlığı altında bir kapı, merdivenin yanlarında birer küçük pencereye yer verilmiştir. Düz silmelerin çerçevelediği enine dikdörtgen biçimli pencereler dekoratif demir şebekelere sahiptir.

Bahçeye bakan batı arka cephe daha yalındır (Resim 10). Köşe plasterleri düz olup yapı boyunca kesintisiz olarak yükselirler. Bunlara bağlanan ince bir yatay silme cephede katları ayırır. Düz ve masif görünümlü cephede simetrik düzende pencerelere yer verilmiştir. Tam ortada, içerideki merdiven kovasına açılan ve dışta kat silmesini kesen ikili pencere grubu yer alır. Hafif basık kemerli olan pencereler diğerlerinden daha uzun tutulmuştur. Bunların üzerinde, saçak altına konumlandırılan iki küçük kare pencere daha yer alır. Orta aksta dikey bir etki oluşturan bu pencerelerin yanlarında, her katta ikişer pencereye yer verilmiştir. Dikdörtgen biçimli pencereler öndekiler gibi hafif basık kemerlidir. Pencerelerin dışa taşkın çerçeveleri dişli olarak düzenlenmiş olup cephede dekoratif bir etki yaratırlar. Cephenin bodrum katında da üstekilerle aynı eksende küçük pencerelere yer verilmiştir. Bunlar ön cephedeki bodrum pencereleriyle aynıdır.

Yapının daha hareketli bir özellik gösteren yan cepheleri simetriktir (Resim 10). Her iki cephede orta kısım iki kat boyunca biraz geri çekilerek hacimsel bir girinti oluşturulmuştur. Bunların cephede meydana getirdiği dikey etki, ortadaki balkon çıkmalarıyla dengelenmiştir. Putrelli balkonlar, ön cephedeki gibi dekoratif demir korkuluklara sahiptir (Resim 11). Üstte, balkona açılan bir kapı ve iki yanında küçük birer pencere yer alır. Balkonların altında üçlü pencereye yer verilmiştir. Giriş katına açılan bu pencereler diğerlerine göre daha dardır. Yan kanatlarda, altta ve üstte ikişer pencere bulunur. Köşe odalarına açılan bu pencereleri, aynı zamanda cepheyi ve katları sınırlayan düz silmeler çerçeveler. Her iki yan cephedeki pencereler arka cephedekilerle aynıdır. Düz bir silmeyle ayrılan bodrum katında da arka cephedekiler gibi küçük pencerelere yer verilmiştir. Bunların haricinde güney yan cephede bodruma açılan bir de kapı bulunur.

Restorasyonlar sırasında konağın kat planlarının yeni işlevine göre değiştirildiği anlaşılmaktadır. Eski planlarda katların eyvanlı orta sofalı diye bilinen plan (Eldem, 1954:25) şemasına göre düzenlendiği görülür (Şekil 3). Ortadaki köşeleri pahlı kare planlı sofanın devamı şeklinde uzanan eyvanlardan; doğudaki giriş hölü, batıdaki merdivenkovası olarak değerlendirilmiştir. Sofanın dört köşesinde birer oda, odalar arasında da birer mekân yer alır. Alt kat odaları pahlı köşelerindeki kapılarla sofaya açı1ırken, üst kat odaları ise ara mekânlarla sofaya ve birbirine bağlanmıştır. Ortadaki kapılarla yan balkonlara açılan ara mekânlardan güneydeki bölünerek tuvalet ve banyo gibi birimlere ayrılmıştır. Konağın bu orta sofalı plan şeması, onarımlar sırasında, yeni işlevine uygun olarak paralel eksenli üç dikdörtgen hacimden oluşan iç sofalı plan şemasına dönüştürülmüş̧ür ${ }^{5}$. Yeni plana göre betonarme olarak inşa edilen iç mekânın (Resim 12) özgün dekorasyonu hakkında bir bilgi yoktur.

\section{Eski Vali Konağı}

Cevatpaşa Mahallesi, İnönü Caddesi, No: 2'de (36 ada, 5 parsel) yer almaktadır. Esasında sivil bir konak olan yapı bir dönem valilik tarafından kullanıldığı için bu ismi almıştır. Konağın inşa tarihine dair bir bilgi yoktur. Dönemin benzer yapıları gibi 19. yüzyılın sonu veya 20. yüzyılın

\footnotetext{
${ }^{5}$ Planlar için bkz., Tolun, 2001, 59-60; Ç.K.V.K.B.K. Arşivi, Dosya No: 17.00.14.
} 
başlarında inşa edilmiş olmalıdır ${ }^{6}$. Yapının mimari üslubu da söz konusu dönemlerin özelliklerini yansıtmaktadır. Konağa ait 1970 tarihli tapu senedinde İl Özel İdare'ye kayıtlı olduğu ve "bahçeli kagir ev" şeklinde tanımlandığı görülmektedir. Bu dönemde İl Özel İdare tarafından Vali Konağı olarak kullanılan bina sonrasında Kız Yetiştirme Yurdu ve Çıraklık Eğitim Merkezi olarak hizmet vermiş, bu kullanımlar esnasında işlevine yönelik bazı değişiklere gidilmiştir (Ç.K.V.K.B.K. Arşivi, Dosya No:17.00.49). Bir süre atıl kalan konak 2003 yılında, Kültür ve Tabiat Varlıklarını Koruma Kurulu'nun hizmet binası olarak Kültür Bakanlığına tahsis edilmiştir. Kültür Bakanlığına tahsis edilen konak henüz hizmete girmeden 2003 ve 2005 yıllarında iki ayrı yangın geçirmiş, bu yangınlar sırasında binanın çatısı, tavanı ve merdivenleri yanmış, bazı ara duvarları ve döşemleri hasar görmüştür (Resim 14) ${ }^{7}$. 2010'da aslına uygun olarak restore edilen konak, günümüzde kültür bakanlığına bağlı Çanakkale Kültür Varlıklarına Koruma Bölge Kurulu Müdürlüğü binası olarak kullanılmaktadır.

Geniş bir bahçesi bulunan konak bodrum üzerine iki katlıdır. Yığma taş şeklinde inşa edildiği anlaşılan konak, bahçenin cadde tarafına yerleştirilmiştir. Yüksek bodrum katıyla birlikte kübik bir kütle teşkil eden yapı kiremit kaplı kırma çatıyla örtülüdür. Neoklasik ağırlıklı eklektik üslubu yansıtan yapıda katlar, tüm cepheleri dolanan silme ve kornişlerle ayrılmış, kat köşelerinde de plasterlere yer verilmiştir. İmpost başlıklara sahip yivli plasterlerin üst kısmında bir madalyon içerisine alınan güneş kursu şeklinde kabaraya yer verilmiştir. Başlıkların üzerinde de kabara hariç benzer şekilde madalyon ve yivler bulunur. Bu başlıklı plasterlere binen kat kornişinin yüzeyi zencirek motifi bezelidir. Saçak altında yer alan üst kat kornişi ise sade tutulmuştur.

Konağın caddeye bakan doğu ön cephe ile bahçeye bakan kuzey yan cephesi diğerlerine göre daha gösterişlidir (Resim 13). Her iki cephenin orta akslarında bir kapı ile yanlarındaki iki küçük pencereden oluşan üçlü açıklığa yer verilmiştir. Ön cephenin giriş katında yer alan üçlü açıklık, çift kollu merdivenle çıkılan bir sahanlığa, diğerleri ise bir balkona açılmaktadır. Bunların üzerinde birer balkon bulunur. Giriş katındaki balkon öndeki iki ayağa binerken üstteki balkonları konsollar destekler. Dekoratif nitelikli bu ' $\mathrm{C} / \mathrm{S}$ ' kıvrımlı konsollar arasında, panolar içerisine yerleştirilen çeşitli bitkisel bezemelere yer verilmiş̧ir (Resim 15). Kalıp tekniğiyle oluşturulan alçı bezemelerden ortadakinde asma dalları, yanlardakinde ise madalyonlar içerisine alınan başak ve akant yaprakları işlidir. Balkon çıkmalarının alt yüzeyinde de ortasında kabaralar bulunan baklava dilimleri şeklinde geometrik kompozisyonlara yer verilmiştir. Ortadaki giriş ve balkon çıkmaları ile hareketlendirilen cephelerin yan kanatlarında ikişer pencere bulunmaktadır. Dikdörtgen formlu kapı ve pencerelerden giriş katındakilerin çerçeveleri dışa taşırılarak vurgulanırken birinci kattakilerin yalnızca üst kısmında böyle bir uygulamaya gidilmiştir (Resim 15). Pencerelerin altında kartuşlara, üstlerinde de 'S' kıvrımlı barok tarzı motiflere yer verilmiştir.

Konağın arka bahçeye bakan batı cephesinde (Resim 13), ön cephedeki giriş ve balkonun yerini ortadaki ikiz pencere gurubu almıştır. Merdivenkovasına açılan düşey eksende üç sıra halindeki ikiz pencerelerden ortadaki diğerlerinden daha uzun tutulmuştur. Daha kısa olan üstekiler saçağa dayanırken, alttakiler bodrum katına sarkmaktadır. Kat kornişlerini kesen ve cephede dikey bir etki yaratan ortadaki bu ikili pencere düzenlenmesinin güneyinde üçer, kuzeyinde ikişer açılığa yer verilmiştir. Her iki katta simetrik olarak tekrarlanan bu açıklıklardan üst katta yer alanlardan biri kap1, diğerleri pencere olarak düzenlenmiştir. Kapılar önlerindeki küçük balkonlara açılır. Cepheye hareket kazandıran demir korkuluklu bu balkonları konsollar destekler. Konsollar arasında baklava dilimleri ve karelerden oluşan geometrik kompozisyonlarla bezeli bir pano yer alır. Güney kanatta yer alan ve cephedeki simetriyi bozan üçüncü pencereler daha küçük tutulmuştur. Cephedeki kapı ve pencereler diğerleriyle aynıdır.

\footnotetext{
${ }^{6}$ Hasan Rami Paşa Konağı ve Hamamı ile aynı civarda yer alan Eski Vali Konağı, mimari olarak da söz konusu konakla benzerlik göstermektedir. Bu bakımından, yukarıda bahsi geçen arşiv belgesindeki (DH.MKT. / 2888-1) Hasan Rami Paşa'ya ait diğer evlerden biri olması da muhtemeldir.

${ }^{7}$ Yangınların neden olduğu tahribat ve restorasyon çalışmaları için bkz., Ç.K.V.K.B.K Arşivi, Dosya No: 17.00.49.
} 
Konağın güney yan cephesi (Resim 13) diğerine göre daha yalın bir düzenlemeye sahiptir. Cephede kesintisiz olarak devam eden silme kornişler yatay bir etki yaratır. Her iki katta, diğer cephedekilerle aynı özellikleri gösteren altışar pencereye yer verilmiştir. Belirli aralıklarla yan yana sıralanan bu pencerelerden orta aksın hemen doğusunda bulunanı diğerlerinden daha küçüktür. Arka cephedekilerle aynı boyuttaki bu küçük pencereler gerisindeki servis mekânlarına açılmaktadır.

Yapının, düz bir silme ile ayrılan yüksek bodrum katı cephelerinde de üstekilerle aynı eksende olmak üzere pencerelere yer verilmiştir. Lento ve söveleri hafif dışa taşırılarak belirtilen yatay dikdörtgen şeklindeki pencereler demir şebekelidir. Bodruma giriş, ön cephedeki merdiven sahanlığı ile kuzey cephedeki balkon altına açılan düz lentolu basit kapılarla sağlanmıştır. Kapıların lento ve söveleri de pencereler gibi hafif dışa taşkındır.

Dıştan kübik kütleli konağın içerisinde iç sofalı plan şeması uygulanmıştır (Şekil 4). Ön cephe aksında yer alan kapıdan doğrudan sofaya girilir. Orta aksta boydan boya uzanan sofanın diğer ucunda merdiven ile bunun güney kenarında küçük bir mekân yer alır. Sofaya paralel olarak iki yanda uzanan dikdörtgen hacimlerden kuzeydeki üç, güneydeki ikiye bölünmüştür. Köşe odalı güney kanadın ortasında tuvalet ve banyoya yer verilmiştir. Odalar birer kapı ile doğrudan sofaya açılırken, kendi içinde bir bütünlük arz eden tuvalet ve banyo önce birer kapı ile öndeki koridora, bu koridor vasıtasıyla da odalara ve sofaya açılmaktadır. Kuzey kanatta ise, bir köşe odası ile salona yer verilmiştir. Esasında köşe odalı ve ara mekânlı olması muhtemel şemada, oda ile ara mekân duvarının sonradan kaldırılmasıyla bu yan salonun oluşturulduğu anlaşılmaktadır. Cephelerde balkonlarla tanımlanan orta mekânlar birer kapı ile köşe odalarına ve sofaya açılmaktadır. Aynı plan şeması üst katta da tekrarlanmış, batı tarafındaki köş̧e odaları birer kapı ile cephedeki küçük balkonlara da açılmıştır. Konağın bağdadi olduğu anlaşılan ara bölücü duvarları ile ahşap tavanları ve çatısı 2003 ve 2005 yıllarındaki yangınlarda büyük oranda yandığı için yenilenmiştir. Genelde sade olduğu görülen yapının yangın sonrası çekilen fotoğraflarında (Resim 14) tavanların pasalı olduğu, üst sofa tavanında çıtalarla oluşturulan geometrik kompozisyonlara yer verildiği, restorasyon sırasında bunların aslına uygun şekilde yenilendiği anlaşılmaktadır (Resim 16).

\section{Değerlendirme ve Sonuç}

Kalenin inşasıyla kurulmaya başlanan, deniz ticaretinin artmasıyla bir liman kenti haline gelen ve giderek gelişen Çanakkale'de, bu süreçte ortaya konan konak ve köşk gibi yapıların çok azı günümüze ulaşabilmiştir. Bunların sayılı örneklerini teşkil eden çalışmamızdaki konaklar 19. yüzyıl sonları ile 20. yüzyıl başlarında inşa edilmiştir. Birçok kez elden geçirilen konaklar plan ve kütle olarak genel özelliklerini korurken yenilenen iç mekanlar eski niteliklerini büyük oranda kaybetmişlerdir. Bir okula dönüştüren Hasan Rami Paşa Konağı'nın iç planı da değiştirilmiştir.

Çalışmada ele alınan konaklar bahçeli olmakla birlikte, eskinin yüksek duvarlarla çevrili harem ve selamlık bölümlerini içeren büyük konaklarından ziyade, çoğu kent konaklarında olduğu gibi (Kuban, 1994:53-54; Orman, 2002:159), daha çok sahibinin sosyal statüsünden dolayı konak olarak adlandırılan ve ön cephe ile bir sokak veya caddeye açılan daha mütevazi yapılar şeklindedirler. Genel hatlarıyla dikdörtgen prizmal bir kütle teşkil eden bu konaklar, yola bağlı cephe gerisinde bodrum üzerine iki katlı olarak yükselmektedirler. Kap1 ve pencerelerle bağlı bulunduğu sokağa açılan yapıların arkasında bahçeli avluları yer almakta olup, Necip Paşa ve Cevat Bey konaklarının bahçelerinde konakların devamı şeklinde uzanan hamam, mutfak ve depo gibi müştemilatlara yer verilmiştir. Konakların bu geometrik kütlesel biçimlenişlerinde ve dışa dönük tasarımlarında, diğer kent konaklarında olduğu gibi, 19. yüzyılın ikinci yarısından itibaren batı kültürü etkisi altında gelişen yeni yaşam tarzı (Kuban, 1995:54; Orman, 2002:159) ile bölgedeki benzer nitelikteki Rum evlerinin (bkz., Erpi, 2006:157; Uçar-Uçar, 2013:128) de etkili olduğu anlaşılmaktadır.

Konakların inşasında genel olarak taş ve tuğla kullanılmış, sadece Necip Paşa Konağı'nın üst katında ahşaba yer verilmiştir. Tamamen kagir olan Hasan Rami Paşa Konağı ve Eski Vali Konağ

Turkish Studies, 15(1) 
taş, Cevat Bey Konağı'nda ise tuğla kullanılmıştır. Bu tür kagir konak ve evleri Çanakkale (Dündar, 2019:3132: Cantay, 1997:91-93) ile birlikte İstanbul (Orman, 2002:160; Şimşek, 2011), İzmir (Akyüz, 1994:34; Erpi, 1987), Aydın (Yener vd., 2012), Edirne (Akansel, 2013:3-11), Tekirdağ (Satkın, 2012:285,293), Kırlareli (Deniz, 2016:64-66,92-94) olmak üzere Batı Anadolu ve Marmara bölgelerinde sıkça görmek mümkündür. Hasan Rami Paşa ve Eski Vali Konağı'nda yığma taş duvarlar sıvayla kapatılırken, Cevat Bey Konağı'nda kırmızı tuğla olduğu gibi cepheye yansıtılmıştır. Başta İtalya olmak üzere Batı'da yaygın olan bu uygulama Çanakkale'deki bir Levanten evinin cephesi ile Nedime Hanım Türbesi ve Mektebi gibi farklı yapılarda da uygulanmıştır (Tombul, 2015:33,45). Bunların dışında, kırmızı tuğlanın Çanakkale evlerinin bazı bölümlerinde he kaplam hem de bir bezeme unsuru olarak sıkça kullanıldığ görülür (Cantay, 1997:19,92). Çanakkale dışında, İzmir'deki Penetti Köşkü (Kuyulu Ersoy, 2006:112-113), Tekirdağ'daki Sarı Köşk (Satkın, 2012:293) ile Büyükada'daki Sivastopol Köşkü ve İstanbul'daki Arvanitidis Köşkü kulesi (Şimşek, 2011:53,137) kırmızı tuğla cepheli diğer bazı örneklerini oluşturmaktadır. Necip Paşa Konağı gibi zemin katın kagir üst katın ahşap olduğu konak ve evlere ise bazı farklılıklarla birlikte, başta Batı ve Kuzey Anadolu olmak üzere hemen her bölgede rastlamak mümkündür (bkz., Kuban, 1995:39; Orman, 2002:160; Levi, 2000:281; Akyüz, 1996:38; Tomsu, 1950; Özhan, 2006; Akın, 2001; Bektaş, 2005). İster kagir ister ahşap olsun çalışmadaki konakların hepsinin iç bölme duvarlarında, geleneksel şekilde tuğla veya kerpiç dolgulu ahşap ile bağdadi tercih edilmiştir.

Dikdörtgen prizmal bir kütle teşkil eden konakların cephe tasarımlarında 19. yüzyıldan itibaren Türk mimarisine giren (Eyice, 1981:169) ve yüzyılın sonlarına doğru evlere de yansıyan (Kuban, 1995:173; Günay, 1998:43-44; Güncan, 1993:167-185; Çıkış, 2009:219) batının neoklasik üslubu etkili olmuştur. Dikdörtgen cepheli konaklarda katlar profilli veya düz silmelerle ayrılmış, köşeler dorik plaster ve sütuncelerle belirtilmiştir. Hasan Rami Paşa ve Eski Vali konaklarının kat silmelerinde zencirek ve diş frizlerine de yer verilmiştir. Yalın bir geometriye dayalı belirli bir simetrinin gözetildiği cephelerden sokağa bakan cepheler diğerlerine göre daha gösterişli tutulmuşlardır. Prestij nitelikli ön cephelerin ortasında kapılara yer verilmiş, pencerelerle birlikte cumba ve balkon gibi çıkmalar kapı eksenine göre simetrik olarak yerleştirilmiştir. Necip Paşa ve Cevat Bey konaklarında kapılar hacimsel bir girinti oluştururken, Hasan Rami Paşa ve Eski Vali konaklarında ise beden duvarıyla aynı hizada dışa açılırlar. Her iki durumda da kapılar, çeşitli plaster ve profilli silmelerle cephelerde vurgulanmıştır. Bu vurgu, Necip Paşa ve Cevat Bey konaklarında kilit taşı öne çıarılan kemerler, Hasan Rami Paşa Konağı'nda da üçgen alınlıkla kuvvetlendirilmiştir. Necip Paşa ve Cevat Bey konakları girişi üzerinde geleneksel nitelikli cumbalara (bkz., Çetin, 2006) yer verilirken, Hasan Rami ve Eski Vali konaklarında bunların yerini balkon çıkmaları almıştır. Orta aksta dikey bir etki yaratan giriş ve çıkmaların iki yanında simetrik konumlu pencereler sıralanmaktadır. Belli bir oranın gözetildiği pencereler dikdörtgen çerçeveli olup Hasan Rami Paşa Konağı'nın her iki katı ile Cevat Bey Konağı'nın üst kat pencereleri hafif basık kemer şeklindedir. Kemerlerin ortasında plastik ifadeli kilit taşlarına yer verilmiştir. Pencere açıklıklarını, Hasan Rami Paşa Konağı'nda profilli, diğerlerinde düz silmeler çerçeveler. Ahşap çerçeveli ve kepenkli Necip Paşa Konağı üst kat pencereleri üçgen alınlıklarla taçlandırılmıştır. Yola bağlı ön cepheler ile dikkat çeken konakların diğer cephelerinde, benzer şekilde doluluk-boşluk oranına bağlı kalınarak plan ve mekânlara göre konumlanan kapı ve pencere açıklıkları alışık olunduğu şekilde yer almışlardır. Daha çok bölgedeki Rum evlerinde rastlanılan (Erpi, 2006:157) ve Çanakkale'de de yaygın olan (Cantay, 1997:69) açık çıkmalar şeklindeki balkonlar da Hasan Rami Paşa ile Eski Vali Konağı'nın cephelerinde kendilerine yer bulmuştur. Birer kapı ile gerisindeki mekâna bağlanan bu balkonları üç yönden işlemeli demir korkuluklar kuşatır. Cephelere dekoratif bir özellik kazandıran neoklasik tarzdaki sütunceler, plasterler, başlıklar, akant yapraklı konsollar, üçgen alınlıklar, kemerler ve diş frizi gibi yapısal ögeler dışında, Eski Vali Konağı'nın balkon altlarında yine antik dönemi refere eden asma dalları şeklinde bitkisel bezmelere yer verilmiştir. Yine aynı konağın her iki katındaki pencerleri ile Necip Paşa Konağı'nın giriş katı pencereleri üzerinde stilize akant yaprağı motifleri bulunmaktadır. Antik dönemin yapısal ve bezeme ögelerine yer verilen 
geometrik simetriye dayalı bu tarz neoklasik cephe tasarımlarına, Çanakkale ile birlikte (Tolun, 2001), özellikle Ege ve Akdeniz ile Marmara bölgesindeki konak ve evlerde sıkça rastlanılmaktadır (bkz., Cantay, 1997:17-32; Erpi, 2006:151-169; Erpi, 1987:203-224; Akyüz, 1994:34; Akyüz, 1996:40; Cevizoğlu, 1996, Çıkış, 2009:220; Renda vd., 1995; Satkın, 2012; Şimşek, 2011; Akansel, 2013:9; Uçar-Uçar, 2013:119-147; Deniz, 2016). Cevat Bey Konağı'nın girişteki ampir tarzı kapısı ve pencerelerin kemer kilit taşlarına işlenen ay-yıldız motifleri ise 19. yüzyıl sonlarında baş gösteren milli mimari arayışlarının bir yansıması olup, bütününde batı ile yerlinin bir sentezini ortaya koyarlar. Bir moda halinde dönemin birçok yapısında rastlanılan (Uysal, 2005:317) bu ay-yıldız motifinin konuttaki benzer bazı örneklerini Çanakkale'deki bir başka ev (Tolun, 2001:140) ile, Aydın Sultanhisar'daki bir ev (Yener vd., 2012:395) teşkil etmektedir.

Kütle ve cephe tasarımılla batılı özellikler gösteren konakların içerisinde geleneksel plan şemalarına yer verilmiş̧tir. Bazı küçük farklılıklar göstermekle birlikte Necip Paşa Konağı, Cevat Bey Konağı ve Eski Vali Konağı'nda iç sofalı, Hasan Rami Paşa Konăğ'nda ise orta sofalı plan tipi kullanılmıştır. İç sofalı olan Necip Paşa ve Cevat Bey konaklarının zemin kat sofalarının önünde bir giriş holüne yer verilmiş olup sofanın diğer ucu birer kapı ile doğrudan bahçeye açılmaktadır. Sofaların dört köşesinde birer oda, sağlı sollu odalar arasında da tuvalet ve banyo ile katlar arası bağlantıyı sağlayan merdivenler yer alır. Aynı planın tekrarlandığı üst katlarda kesintisiz olarak uzanan sofalar öne doğru taşarak giriş üzerinde çıkmalar oluşturlar. Eski vali konağında ise sofa her iki katta da boydan boya uzanmakta olup bir ucunda doğrudan dışa açılan kapı, diğer ucunda ise merdiven kuruluşu yer almaktadır. Sofanın iki yanındaki odalar birer kapı ile doğrudan sofaya açılırken ardaki tuvalet ve banyo bir koridor vasıtasıyla solana açılmaktadır. Kabaca, paralel eksenli üç dikdörtgen hacimden oluşan ve "karnıyarık" olarak da ifade edilen bu iç sofalı plan şeması, daha çok 19. yüzyıldan itibaren yaygınlık kazanmış olup Osmanlı'nın hemen her bölgesinde görülmektedir (bkz., Eldem, 1954:91-126). Hasan Rami Paşa Konağı'nda kullanılan orta sofa, köşe pahlı ve iki eyvanlı şeklinde teşkil edilmiş̧ir. Eyvanın biri giriş, diğeri de merdiven kovası olarak değerlendirilmiştir. Birer kapı ile sofaya açılan köşe odaları arasında ise ara mekanlara yer verilmiş̧ir. Esasen geçmişi çok eskilere uzanan merkezi planın (Akın, 1990; Kuban, 1995:64) yeni bir versiyonu olan bu orta sofalı plan tipinin farklı türlerine başta İstanbul olmak üzere birçok kentete rastlamak mümkündür (bkz., Eldem, 1954: 127-148). Üsküdar'daki Türkmenzade İsmail Konağ1, Bolu'daki Bay Muhittin Evi, Bebek'teki Kavafyan Evi, İstanbul Çengelköy Caddesi üzerindeki bir ev (Eldem, 1954: 136-138) ile Bulgaristan Nessebar'daki Muskoyanin ve Küçügü̈n evleri (Akın, 2001:53), Midilli'deki Vareltzidis Evi (Akın, 2001:104) orta sofalı plan tipinin köşe pahlı ve iki eyvanlı türünün bazı örneklerini oluşturmaktadır.

Konaklardan, Hasan Rami Paşa haricindekiler genel plan şemalarını korumakla birlikte iç mekânları büyük oranda yenilenmiş olup, özgün dekorasyonu ve süslemeleri pek bilinmemektedir. Ancak, restorasyonlar öncesi fotoğraflarda genel itibariyle tavanların pasalı olduğu, Necip Paşa ve Cevat Bey konaklarının giriş holü ve sofa tavanları ile Eski Vali Konă̆ı'nın üst sofa tavanında profilli çıtalarla teşkil olunan geometrik kompozisyonlara yer verildiği görülür. Ayrıca, Necip Paşa Konağı üst kat sofasının tavan eteklerinde dekoratif ahşap konsollar ile bunlar arasında uzanan diş frizleri ve profilli silmelere de yer verilmiştir. Bunların dışında, Cevat Bey Konağı'ndaki gibi merdivenlerin işlemeli korkuluk ve tırabzanları da içerideki süslemelere dahil edilebilir. Sınırlı düzeydeki bu iç mekân süslemelerinin bir kısmının restorasyonlar sırasında aslına uygun olarak yenilendiği anlaşılmaktadır. Tavanlarda profilli çıtalarla oluşturulan geometrik süslemelere eskiden beri hemen her bölgelerdeki Türk konak ve evlerinde rastlamak mümkündür (bkz., Kuban, 1995:133; Küçükerman, 1996:167; Günay, 1998:304; Rıfat Osman, 1976;21; Satkın, 2012:213-217). Tavan eteklerinde görülen neoklasik etkili dekoratif konsol dizileri ve diş frizleri şeklindeki bezemler ise 19. yüzyıldan itibaren yaygınlık kazanmış olup, daha çok gayrimüslimlerin yoğun olduğu Batı Anadolu kıyılarındaki konak ve evlerde görülmektedir. Çanakkale'deki Vitalis Köşkü (Dündar, 2019:309), İzmir Bornova'da Murad Köşkü (Kuyulu, 2006:188; Levi vd., 2007:16), Edirne'de İlhan 
Koman Evi (Akansel, 2013:14-15), Tekirdağ'da Sarı Köşk (Satkın, 2012:295) bunların bazılarını oluşturmaktadır.

Sonuç olarak, yüksek gelirli ve önemli kişiler tarafından inşa ettirildikleri anlaşılan Çanakkale'deki bu bahçeli konaklar kentin önemli mimari eserlerini teşkil etmekte olup, sahiplerinin ekonomik ve sosyal durumları ile kültürel eğilimlerini ortaya koymaktadır. Gerek kullanılan malzeme-teknik, gerekse cephe ve plan kuruluşlarıyla dikkati çeken bu tarz konaklara, özellikle Ege ve Adalar ile Marmara bölgesinde sıkça rastlamak mümkündür. Genel itibariyle döneminin ve bölgenin mimari anlayışı ile sosyo-kültürel etkilerini yansıtan Necip Paşa, Hasan Rami Paşa, Cevat Bey ve Eski Vali Konağı, Osmanlı'nın son dönemlerinde inşa edilen bu tarz yapıların Çanakkale'deki sayılı örneklerini teşkil etmesi bakımından önem arz etmektedirler.

\section{KAYNAKÇA}

Acıoğlu, Y. (2015). "Çanakkale'deki Osmanlı Kaleleri”. Çanakkale Araştırmaları Türk Yıllığı, 19: 93-122.

Akansel, (2013). "Edirne Kaleiçi Tarihi Konutları". Edirne Taşınmaz Kültür Varlıkları Envanteri II, 2-174. Edirne: Edirne Valiliği İl Kültür ve Müdürlügüü. DOI:https://doi.org/10.22520/tubaked.2010.0003

Akın, G. (1990). Asya Merkezi Mekan Geleneği. Ankara: Kültür Bakanlığ1 Yayınları.

Akın, N. (2001). Balkanlarda Osmanlı Dönemi Mimarisi. İstanbul: literatür Yayıncılık.

Akkurt, H. (2004). "Batılı Kültürün 19. Yüzyıl İzmir'inde Mekansal Temsili: Bornova ve Buca Levanten Evleri”. Egemimarlık, 3/51: 4-9.

Akyüz, E. (1994). “Tarihsel Süreçte İzmir'de Konut”. Egemimarlık, 3/14: 32-35.

Akyüz, E. (1996). “İzmir Evleri”. Atlas Özel Sayı, İzmir’96: 34-42.

Anonim, (1971). "Hasan Rami Paşa”. Türk Ansiklopedisi, XIX: 24-25. Ankara: Milli Eğitim Bakanlığı.

Aslan, H. (2006). “Okulumuzun Tarihçesi”. 18 Mart İlköğretim Okulu Bülteni, 3: 28.

Atabay, M. (2012). "Çanakkale'de Nüfus Yapısı, Niteliği ve Göçler”. Aşklar, Savaşlar, Kahramanlar ve Çanakkale, 409-427. İstanbul: Yap1 Kredi.

Bektaş, C. (2005). Antalya Evleri. İstanbul: Bileşim yayınları.

Cantay, G. (Ed., İ. Erten). (1997). Çanakkale Yapıları Tasarım Rehberi. Çanakkale: Çanakkale Belediyesi.

Cevizoğlu, H. (1996). Aydın Evlerinin Cephelerinde Kullanılan Süsleme Elemanlarının Antikçă̆ Mimarisi ile Karşılaştırılması. Aydın: Mimarlar Odası Aydın Temsilciliği.

Cuinet, V. (1894). La Turquie D’Asie, Géographie Administrative, Tome Troisieme, Paris.

Çanakkale Kültür Varlıklarını Koruma Bölge Kurulu Arşivi. Dosya No: 17.00.3; Dosya No: 17.00.14; Dosya No: 17.00.15; Dosya No: 17.00.49.

Çelik, S. (2012). "Evliya Çelebi’nin, Sultan IV. Mehmed ile Birlikte Katıldığı Bursa ve Çanakkale Boğazı Gezisi”. Balıkesir Üniversitesi Sosyal Bilimler Enstitüsü Dergisi, 15/28: 139-197. DOI: https://doi.org/10.31795/baunsobed.657002

Çetin, Y. (2006). “Geleneksel Türk Evinde Cumbalar”, Sanat Tarihi Dergisi, XV/2: 17-27. 
Çıkış, S. (2009). “'Modern Konut’ Olarak XIX. Yüzyıl İzmir Konutu: Biçimsel ve Kavramsal Ortaklıklar". METU.JFA, 26/2: 211-233. DOI: https://doi.org/10.4305/metu.jfa.2009.2.11

Çoruhlu, T. (2008). "Çanakkale İlinde Sivil Mimari”. Çanakkale Tarihi, VI, 3445-3453. İstanbul: Değişim.

Deniz, E. (2016). Kırklareli Konut Yapılarında Kalemişi Süsleme. Yayımlanmamış Yüksek Lisans Tezi, Onsekiz Mart Üniversitesi Sosyal Bilimler Enstitüsü, Çanakkale.

Devlet Arşivleri, DH.MKT. / 2888-1 (H.13.07.1327); DH.MUİ. / 85-50 (H.28.04.1328).

Dündar, M. (2019). “Çanakkale'de İki Levanten Evi: Vitalis Konağı ve Whittall Konağı”. Çanakkale Araştırmaları Türk Yllı̆̆l, DOI:https://doi.org/10.17518/canakkalearastirmalari.585374

Eldem, S. H. (1954). Türk Evi Plan Tipleri. İstanbul: İstanbul Teknik Üniversitesi Mimarlık Fakültesi.

Erpi, F. (1987). Buca'da Konut Mimarisi (1838-1934). Ankara: Ortadoğu Teknik Üniversitesi.

Erpi, F. (2006). "Toplum Kültürü ve Yerel Mimaride Yansıması- Üç Örnek: Batı Anadolu'da Türk, Rum ve Levanten Konutları". Avrupalı mi Levanten Mi? (Yay. Haz., A. Yumul - F. Dikkaya), 151-169. İstanbul: Bağlam Yayınc1lık.

Erten, İ. (2012). “Çanakkale Yerleşim Kültürü”. Aşklar, Savaşlar, Kahramanlar ve Çanakkale, 385408. İstanbul: Yap1 Kredi.

Eyice, S. (1981). "XVIII. Yüzy1lda Türk Sanatı ve Türk Mimarisinde Avrupa Neo-Klasik Üslubu". Sanat Tarihi Yılliğl, IX-X, 163-189.

Günay, R. (1998). Türk Ev Geleneği ve Safranbolu Evleri. İstanbul: Yap1-Endüstri Merkezi Yayınlar1.

Güncan, M. A. (1993). 19. Yüzyll Avrupa Mimarlık Hareketlerinin ve Batılılaşmanın Osmanlı Konut Mimarisine Etkileri. Yayınlanmamış Yüksek Lisans Tezi, İstanbul Teknik Üniversitesi Fen Bilimleri Enstitüsü, İstanbul.

Hasan Rami Paşa, (1324). Hatırat (1). İstanbul:

Hasol, D. (2012). Ansiklopedik Mimarlı Sözlüğ̈̈. İstanbul: Yapı-Endüstri Merkezi Yayınları.

Jewish, V. (2012). The social and economic position of Jews in Macedonia in the XIXth century, 14-15. (http://www.paideia-eu.org/wp-content/uploads/2012/08/Vladimir-Janev.pdf) DOI:https://doi.org/10.18411/d-2016-154

Kahraman, S. A. vd. (Yay. Haz.). (2001). Evliyâ Çelebi Seyahatnamesi- 5. Kitap. İstanbul: Yap1 Kredi.

Kalfa, M. Ş. (2008). "Bir Portre ve Kentte Geçmişin Ayak İzleri 2: Hasan Rami Paşa (1842-1923)". Troy Çanakkale, 31: 32-35.

Koçyiğit, O. (2017). “Çanakkale’nin Geç Osmanlı Devri Kültür Mirası: Ticaret ve Üretim Yapıları". TÜBA-KED, 15: 127-138. DOI: https://doi.org/10.22520/tubaked.2017.15.008

Kuban, D. (1994). “Konaklar”. Dünden Bugüne İstanbul Ansiklopedisi, 5: 50-55.

Kuban, D. (1995). Türk “Hayat”lı Evi. İstanbul: Ziraat Bankası Kültür Yayınları.

Kulu, M. M. (2008). "Çanakkale Yerel Tarihi İle İlgili Bir Kaynak: Vilayet Salnameleri”. Çanakkale Tarihi, III, 1303-1361. İstanbul: Değişim. 
Kuyulu Ersoy, İ. (2006). "Karşıyaka Levanten Konutlarından Örnekler”. Karşıyaka Kültür ve Çevre Seтроzуити (22-23 Aralık 2005) Bildiriler), 35-47. İzmir: Karşıyaka Belediyesi Kültür Yayınları.

Kuyulu, İ. (2006). "Bornova'da Levanten Konutları". Avrupalı mı Levanten Mi? (Yay. Haz., A. Yumul - F. Dikkaya), 171-197. İstanbul: Bağlam Yayıncılık.

Küçükerman, Ö. (1996). Kendi Mekânın Arayışı İçinde Türk Evi. İstanbul: Türkiye Turing ve Otomobil Kurumu.

Levi, E. A. (2000). "Batı Anadolu Kıyıları Konut Mimarisinin Ege Adalarındaki Örneklerle Karşılaştırmalı Değerlendirmesi”. Osmanlı Mimarlığının 7 Yüzyılı "Uluslarüstü Bir Miras”, 277-285. İstanbul: Yapı-Endüstri Merkezi Yayınları.

Levi E. A. vd. (2007). "Bornova - Edwars (Murad) Köşkü Restorasyon Çalışmaları”. Egemimarlık, 1/60: 14-19.

Orman, İ. (2002). “Konak”. Türkiye Diyanet Vakfi İslam Ansiklopedisi, 26:159-161.

Özhan, N. (2006). Anadolu'nun Geleneksel Konutlarında Ahşap Kullanımına Ait Bir Derleme. Yayınlanmamış Yüksek Lisans Tezi, Ankara: Gazi Üniversitesi Fen Bilimleri Enstitüsü.

Renda, G. vd. (1995). Mersin Evleri. Ankara: Kültür Bakanlığı Yayınları.

Rifat Osman. (1976). Edirne Evleri, (Yay. Haz., S. Ünver). İstanbul. Türkiye Turing ve Otomobil Kurumu.

Satkın, N. (2012). Osmanlı Dönemi Tekirdă̆ Evleri. Tekirdağ: Tekirdağ Valiliği Yayını.

Tolun, N. (2001). Canakkale'de 18. ve 19. Yüzyll Konut Mimarisi. Yayımlanmamı̣ Yüksek Lisans Tezi, Onsekiz Mart Üniversitesi Sosyal Bilimler Enstitüsü, Çanakkale.

Tolun, V. (2012). “Osmanlı'nın Akdeniz'e Açılan Kapısı: Çanakkale”. Aşklar, Savaşlar, Kahramanlar ve Çanakkale, 11-162. İstanbul: Yap1 Kredi.

Tombul, M. (2015). Çanakkale Kültür Envanteri. İstanbul: Çanakkale Valiliği.

Tomsu, L. (1950). Bursa Evleri. İstanbul: İstanbul Teknik Üniversitesi Mimarlık Fakültesi.

Tuncel, M. (1993). "Çanakkale”. Türkiye Diyanet Vakfi İslam Ansiklopedisi, 8: 197-199.

Uçar, H. - Uçar, A. (2013). "İzmir Kemeraltı Geleneksel Kent Dokusunda Konut Tipleri ve Cephe Tipolojisi”. Sanat Tarihi Dergisi, XXII / 2: 119-147.

Uygun, S. (2015). Çanakkale'nin Eğitim Mirası. İstanbul.

Uysal, Z. (2005). "Yeşilyurt Köyü Cami”. Sanat Tarihi Dergisi, XIV/1: 309-329.

Yener, E. vd. (Haz.). (2012). Aydın Kültür Envanteri - I. Ankara: Aydın Valiliği İl Kültür ve Turizm Müdürlüğü Yayınları. 


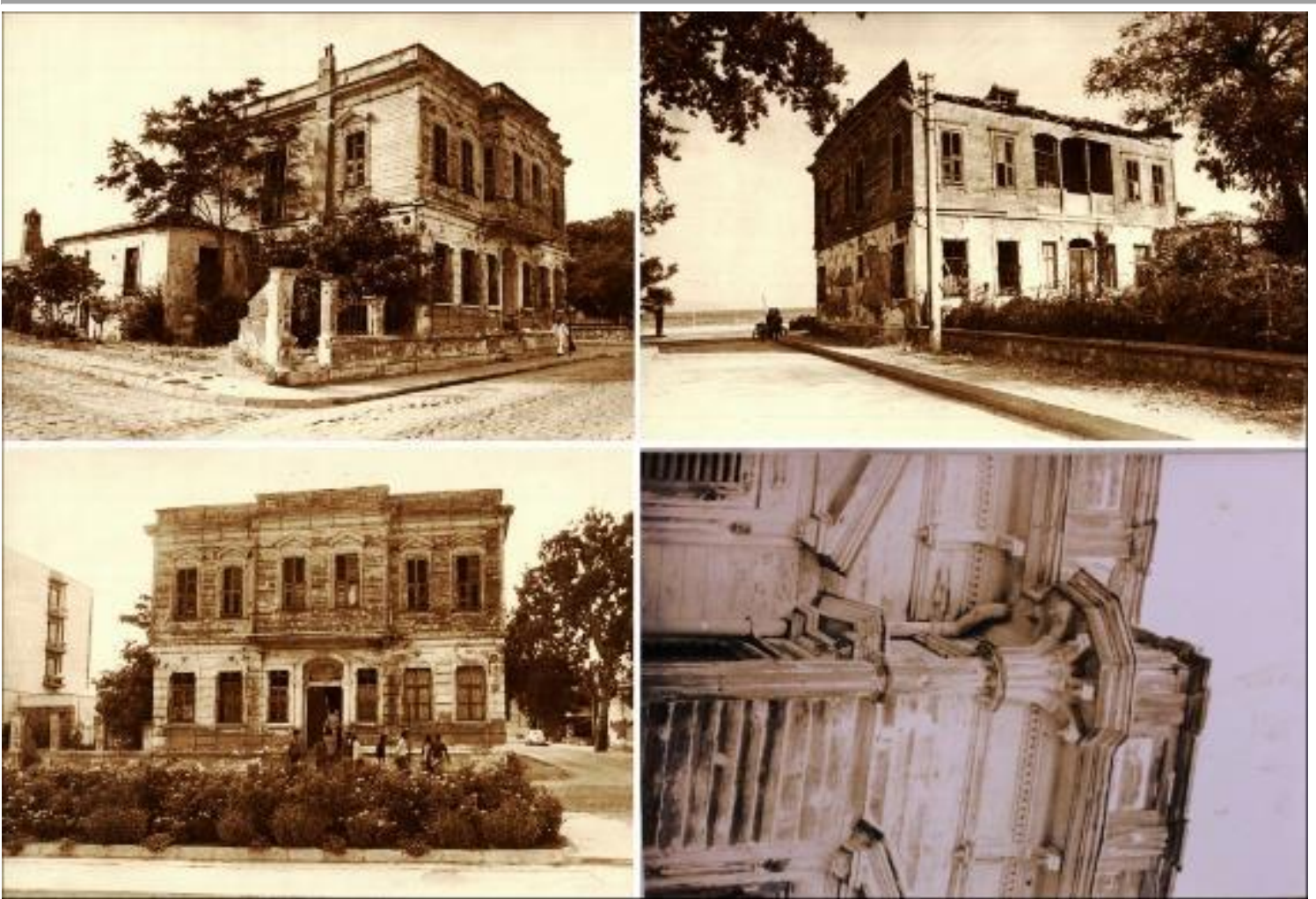

Resim 1: Necip Paşa Konăğ, 1970’lere ait arşiv fotoğrafları (Ç.K.V.K.B.K. Arşivi).
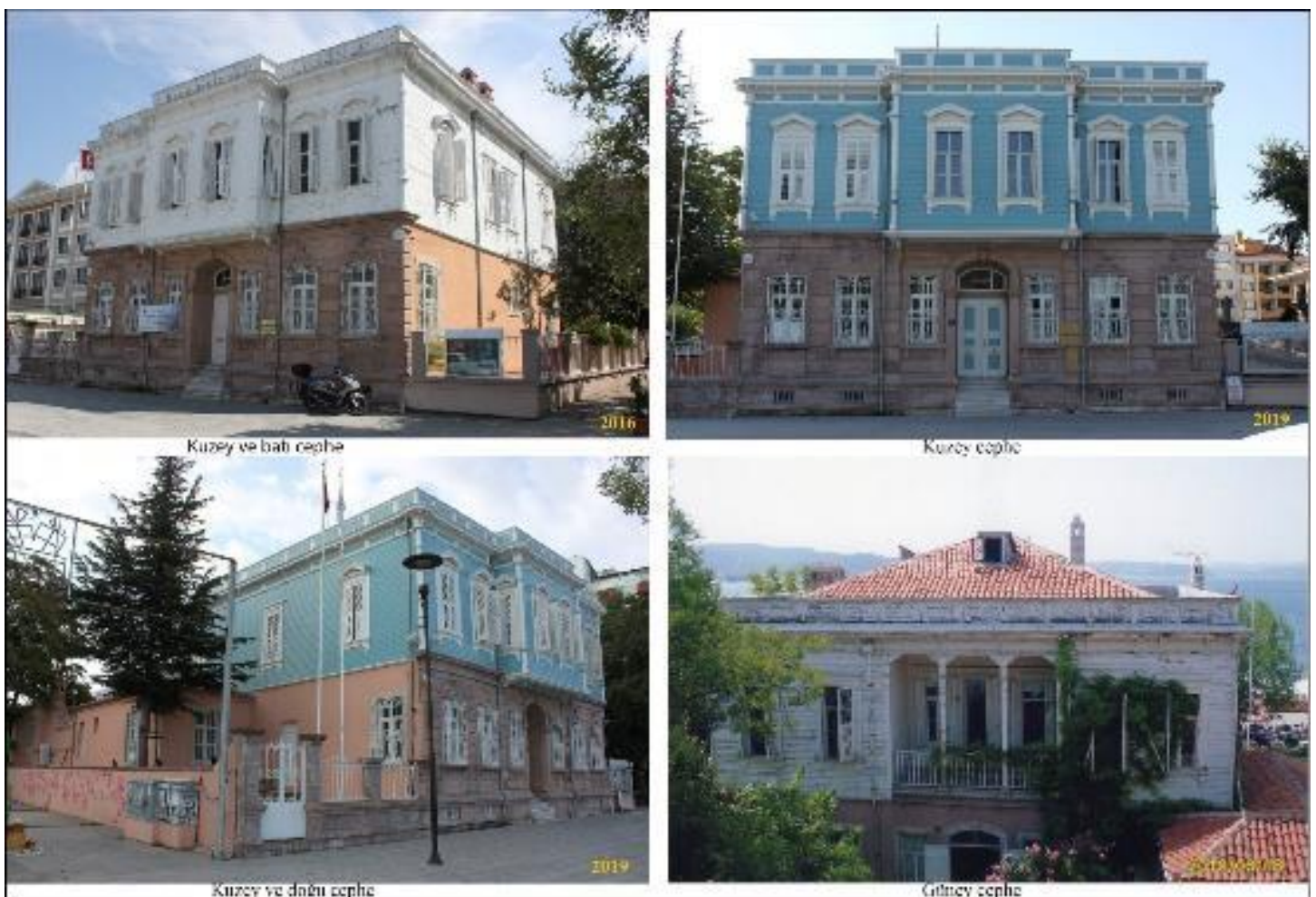

Resim 2: Necip Paşa Konağı, cephe görünümleri. 

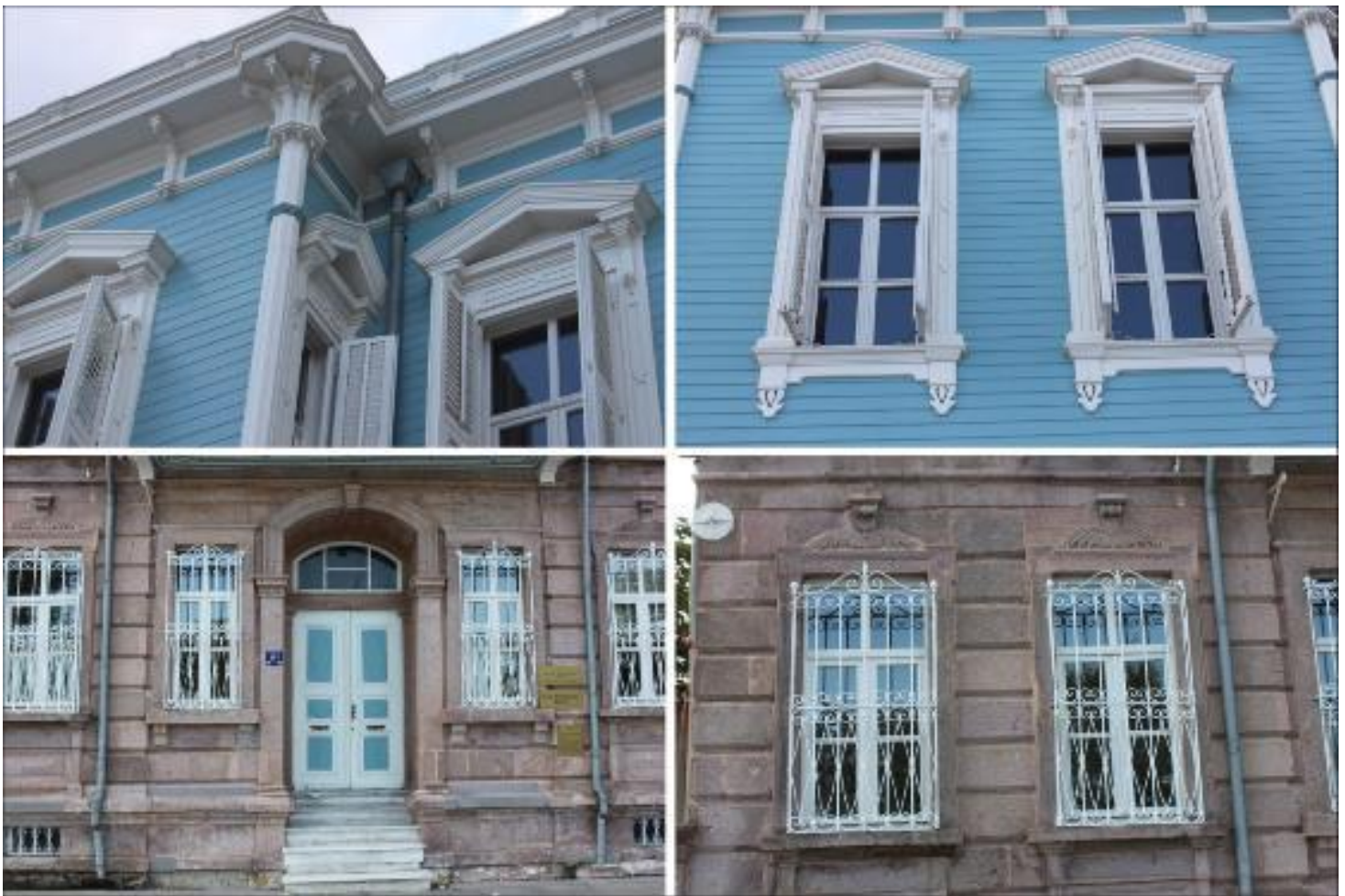

Resim 3: Necip Paşa Konağı, ön cephe detayları. (2019)

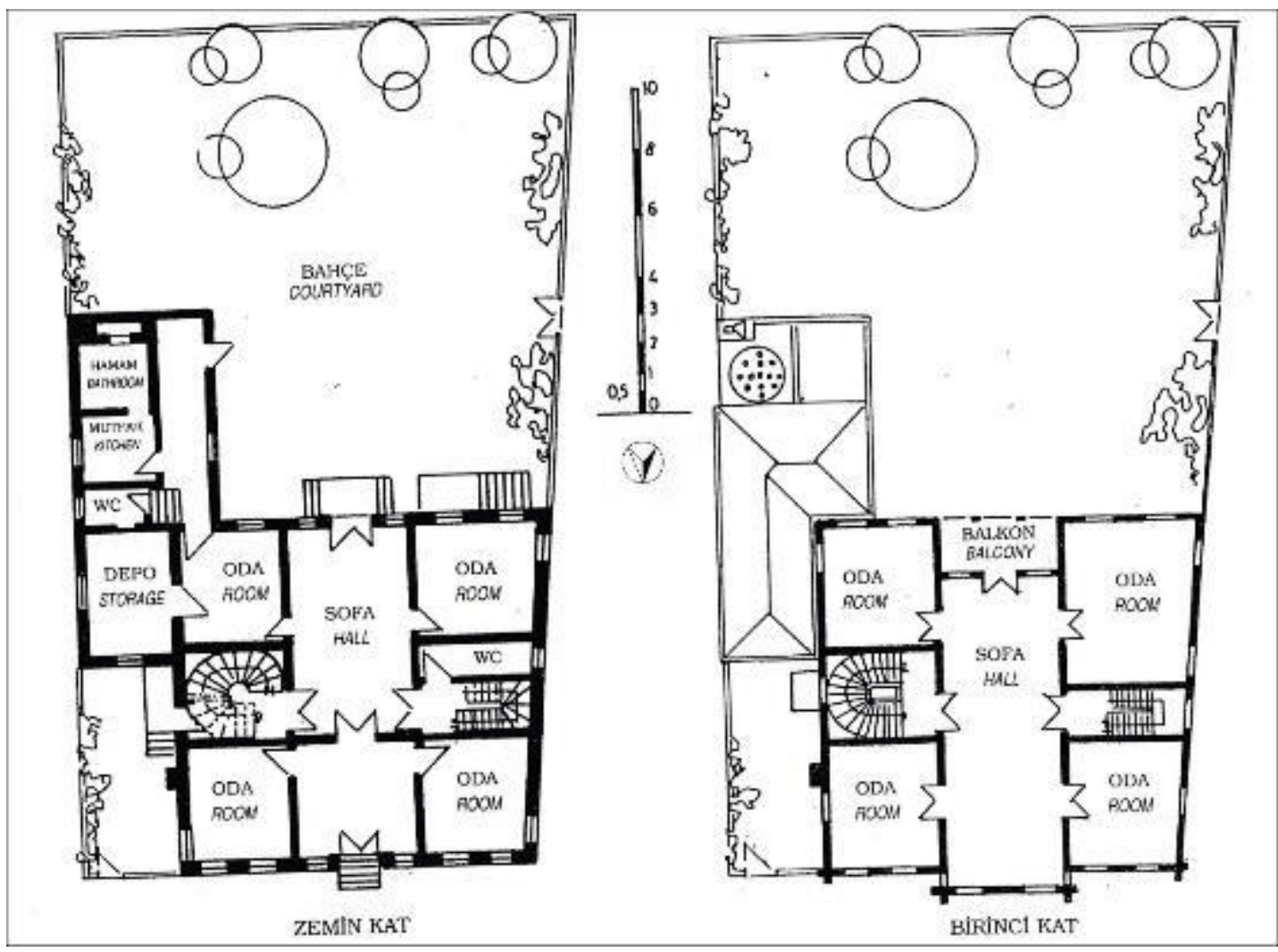

Şekil 1: Necip Paşa Konağı, kat planları (N. A. Hacıalioğlu / Çanakkale Yapıları Tasarım Rehberi). 

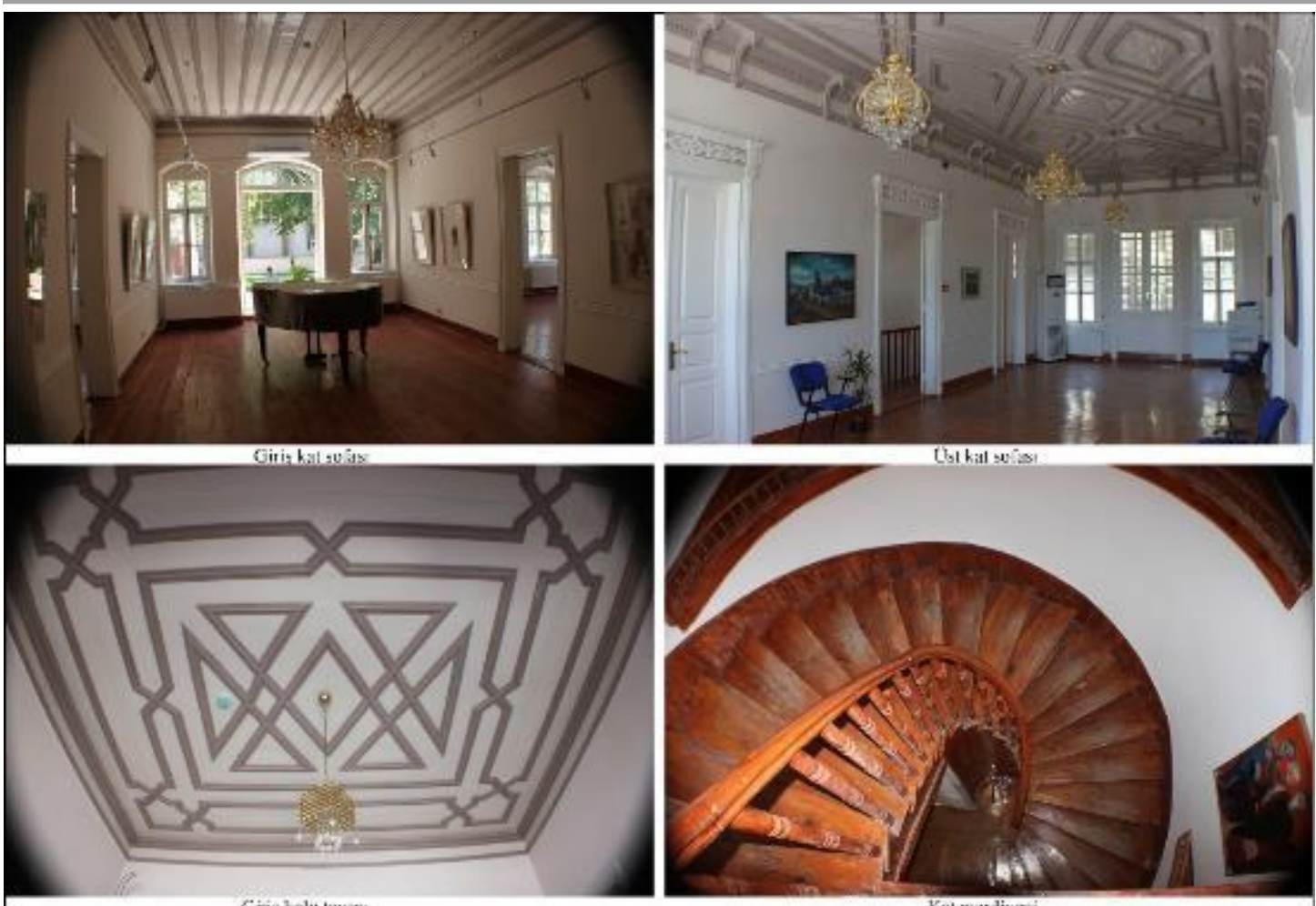

Resim 4: Necip Paşa Konağı, iç mekân görünümleri. (2013)

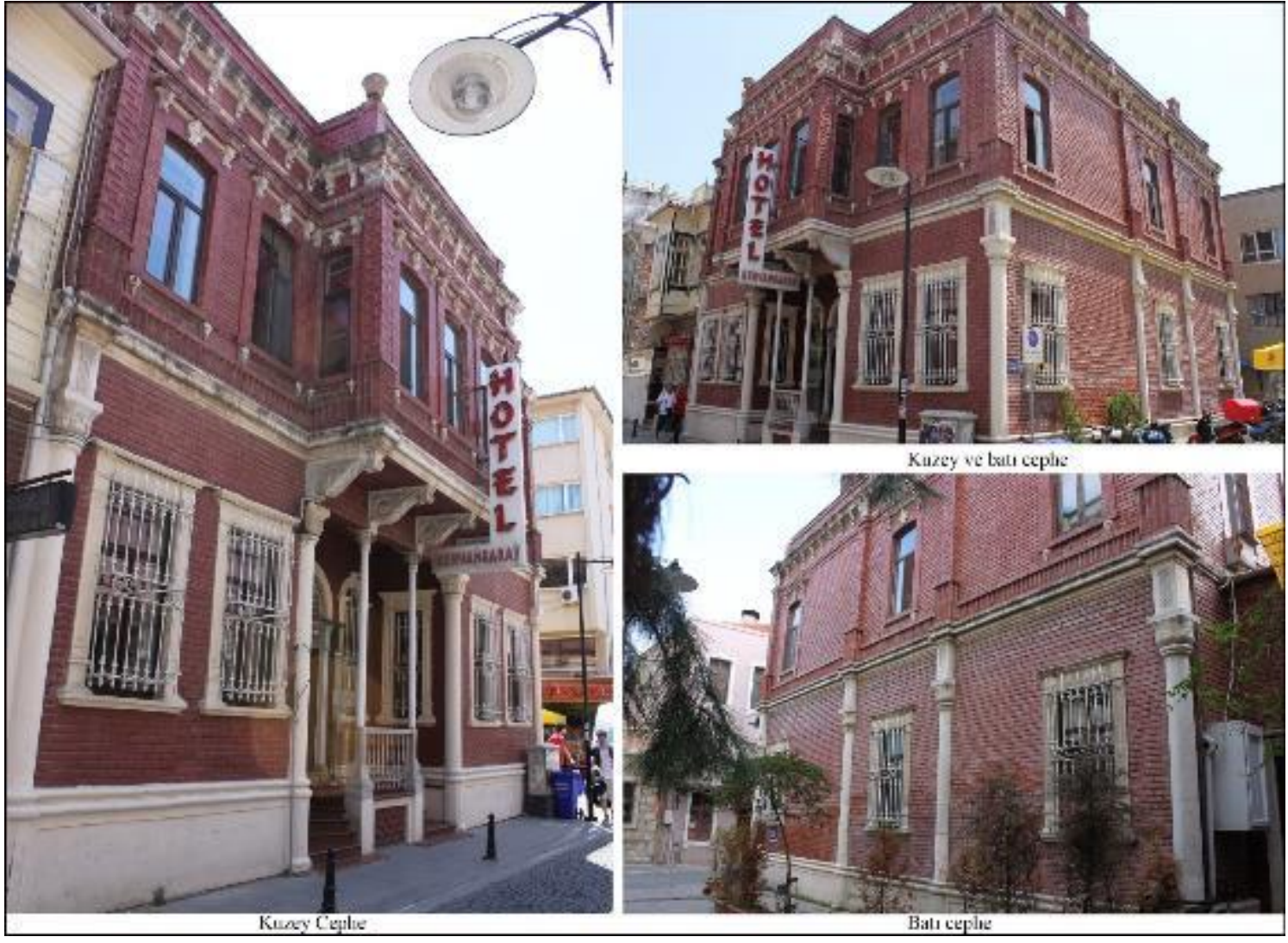

Resim 5: Cevat Bey Konağı, cephe görünümleri. (2018)

Turkish Studies, 15(1) 


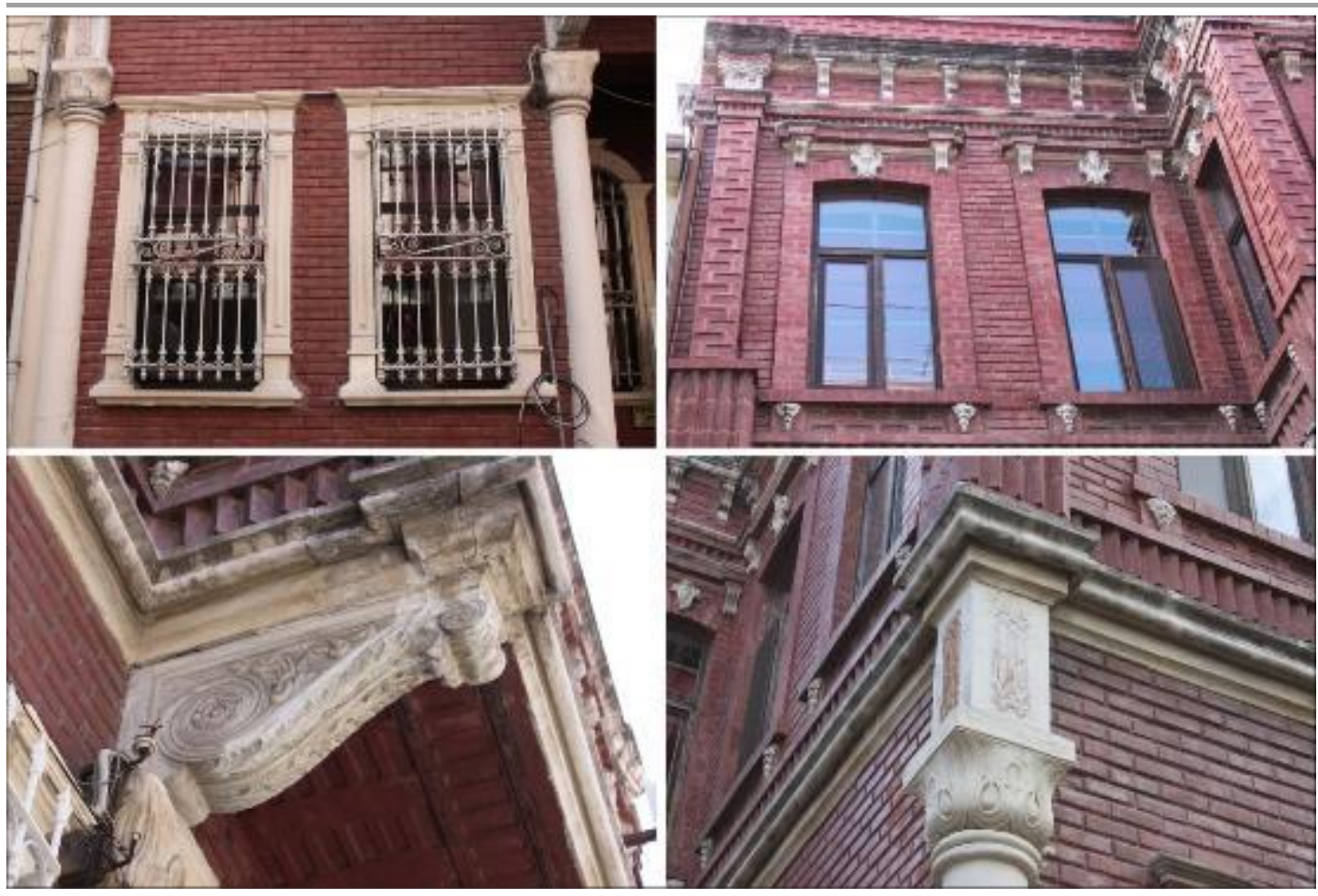

Resim 6: Cevat Bey Konağı, ön cephe detayları. (2018)

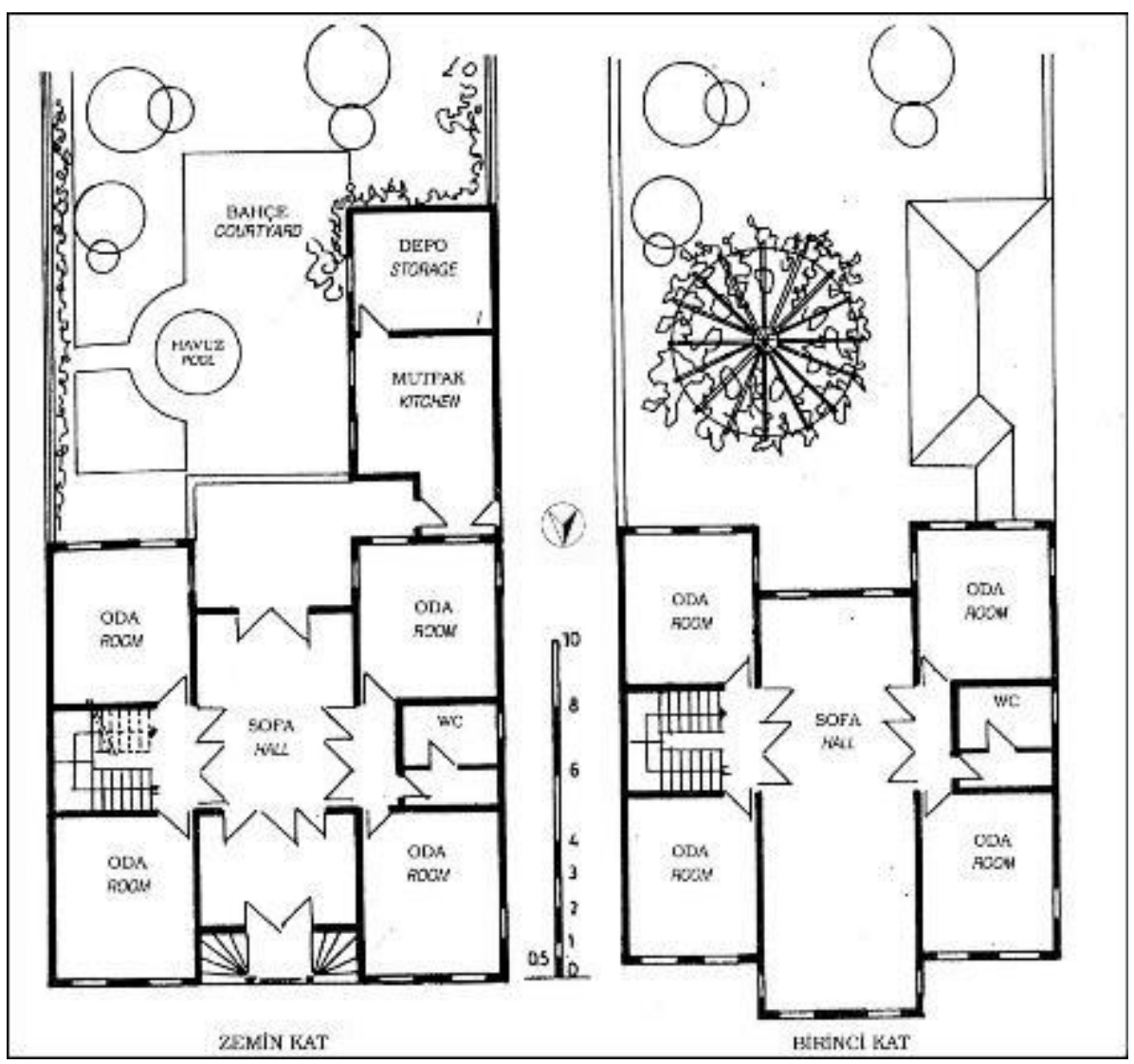

Şekil 2: Cevat Bey Konağı, kat planları (N. A. Hacıalioğlu / Çanakkale Yapıları Tasarım Rehberi). 


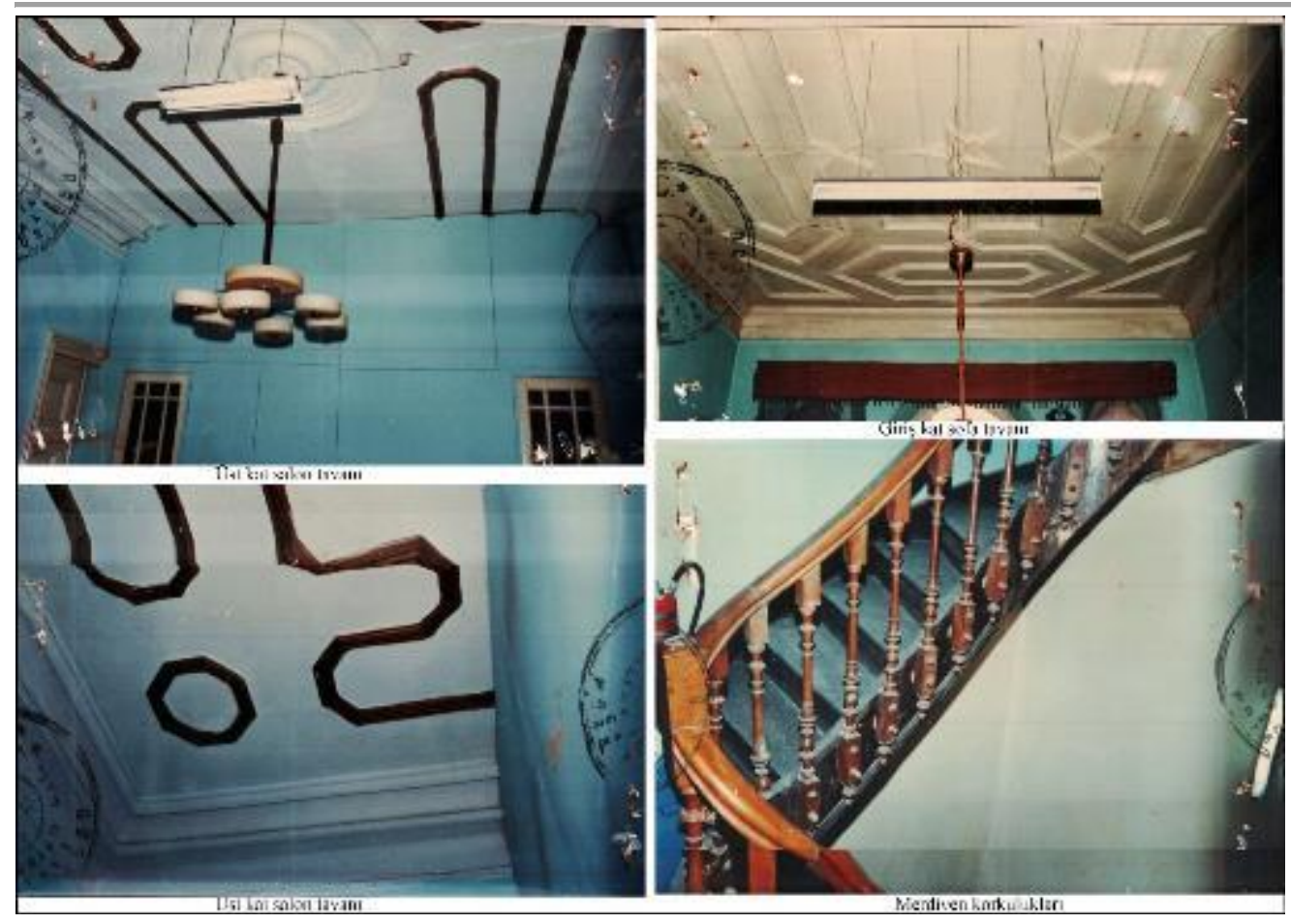

Resim 7: Cevat Bey Konağı, restorasyon öncesi iç mekân görünümleri (Ç.K.V.K.B.K. Arşivi). (1986)

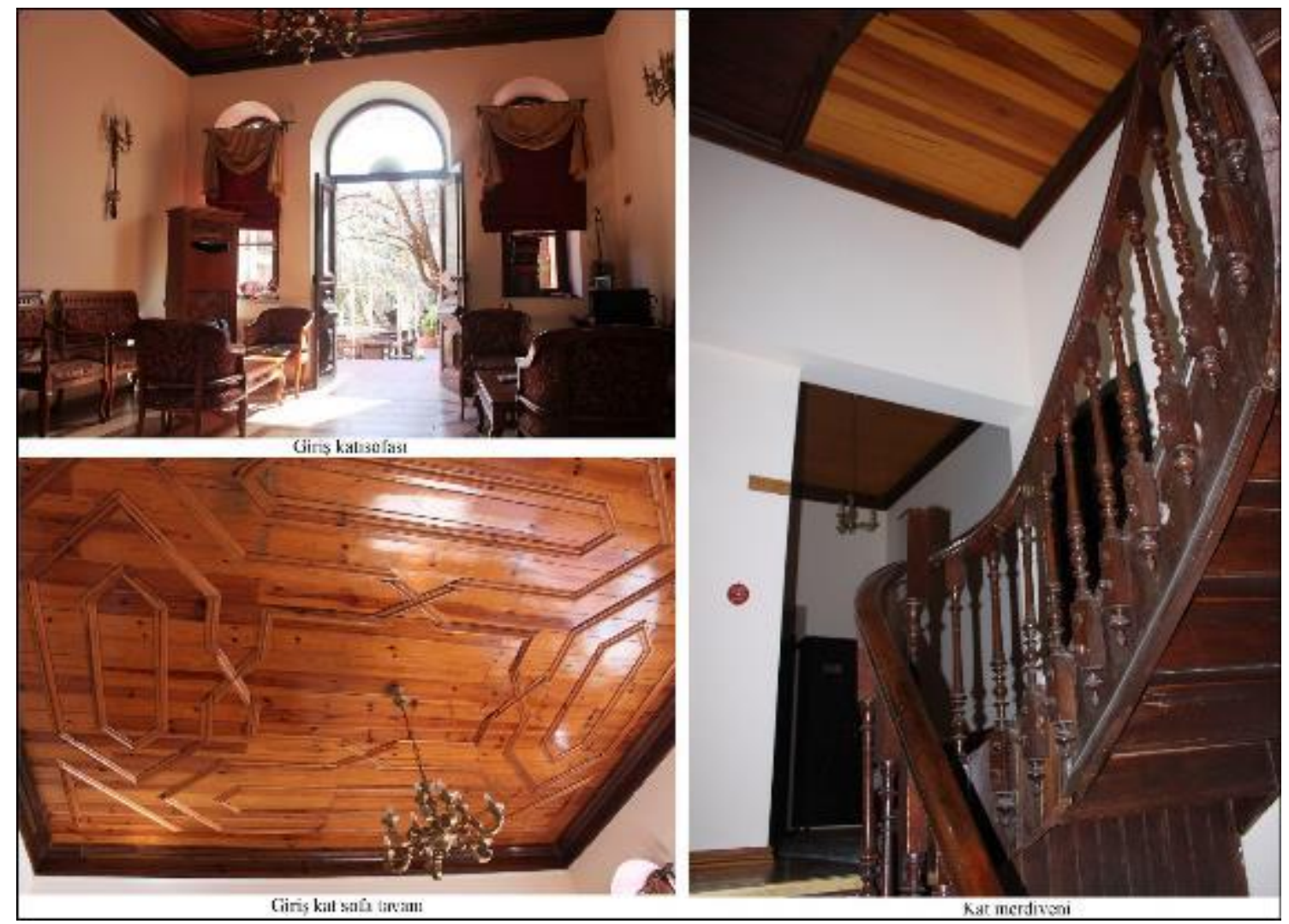

Resim 8: Cevat Bey Konağı, iç mekân görünümleri. (2018) 

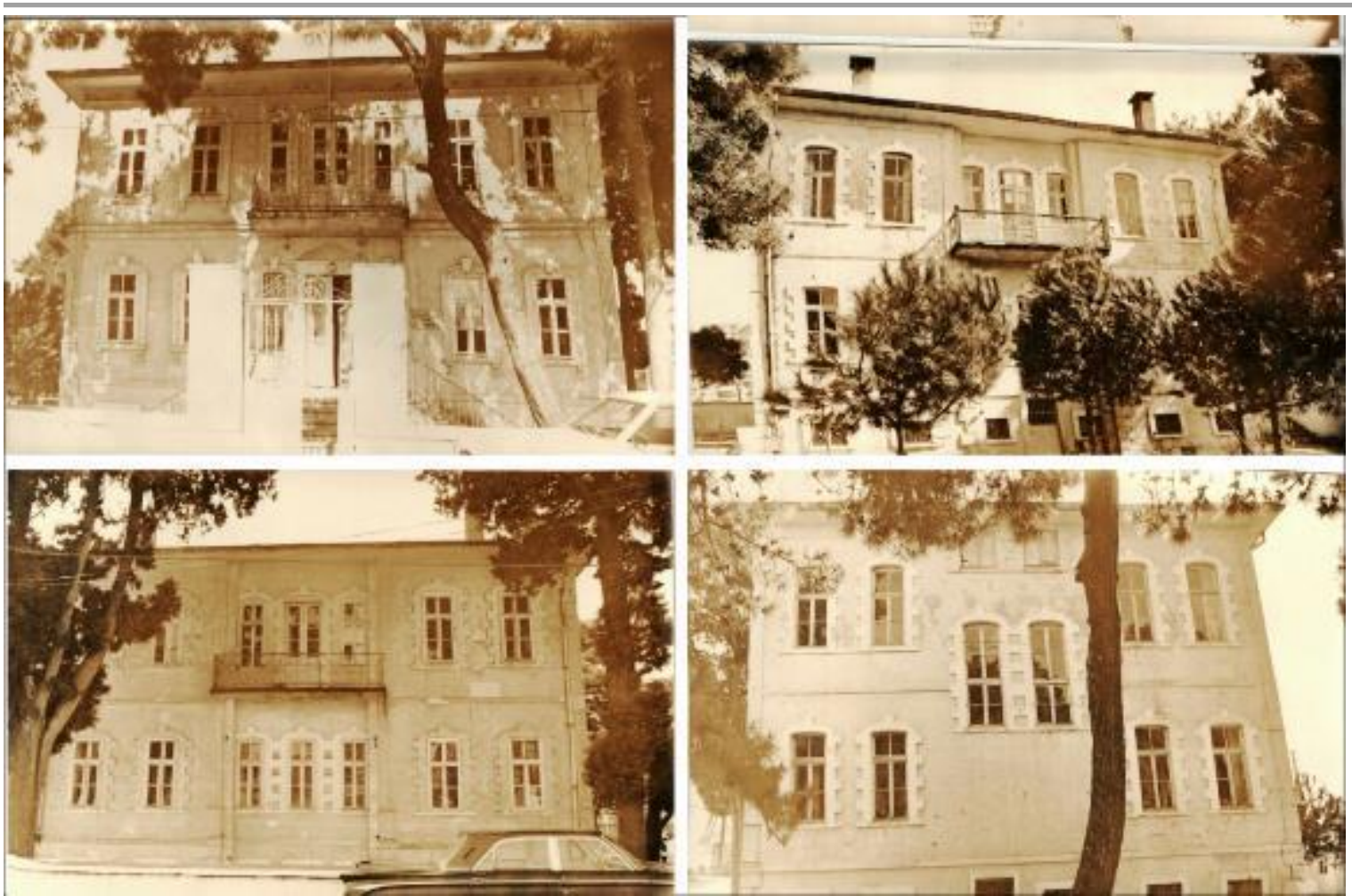

Resim 9: Hasan Rami Paşa Konă̆ı, arşiv fotoğrafları (ÇKVKBK Arşivi). (1983)

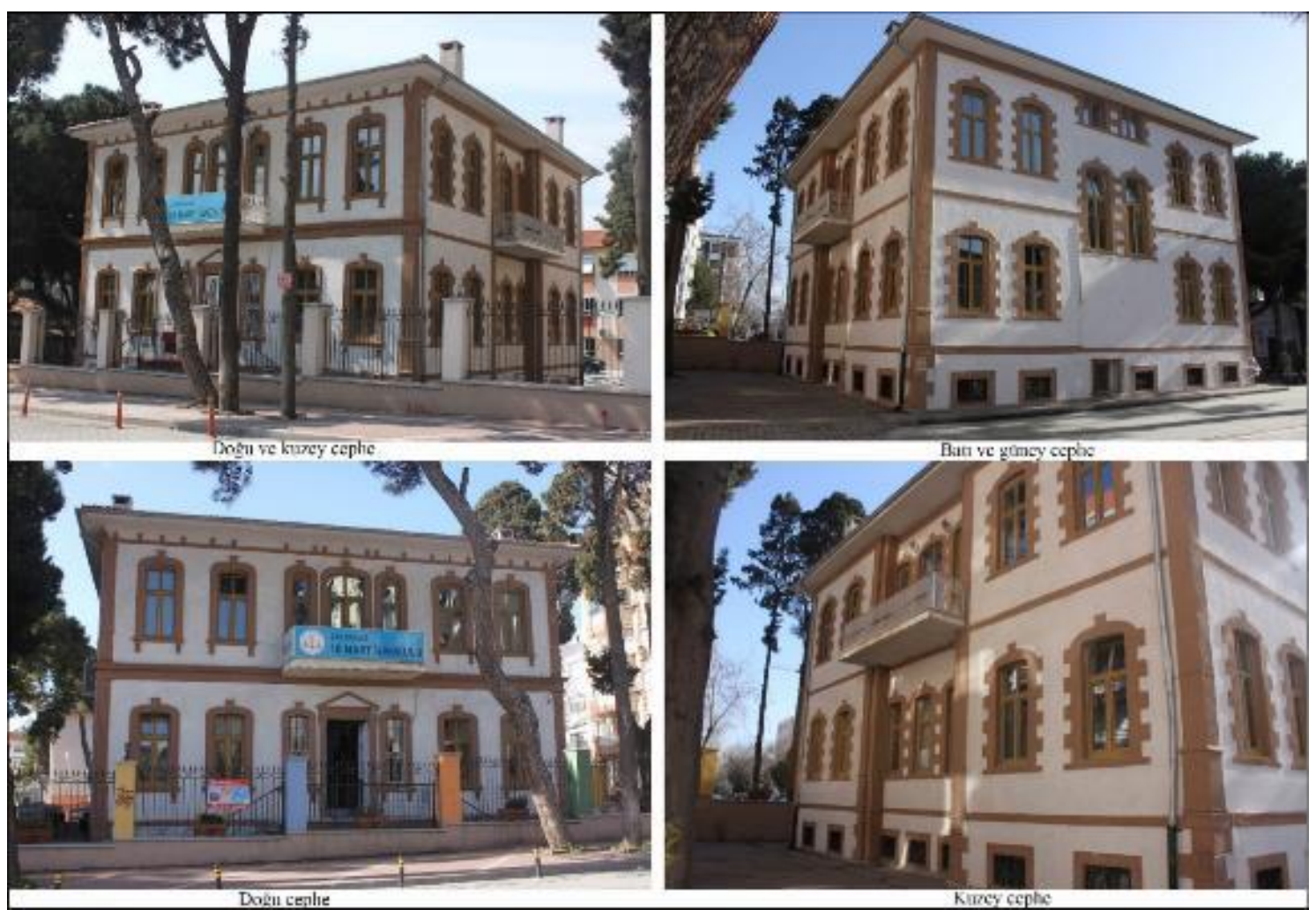

Resim 10: Hasan Rami Paşa Konağı, cephe görünümleri. (2018) 

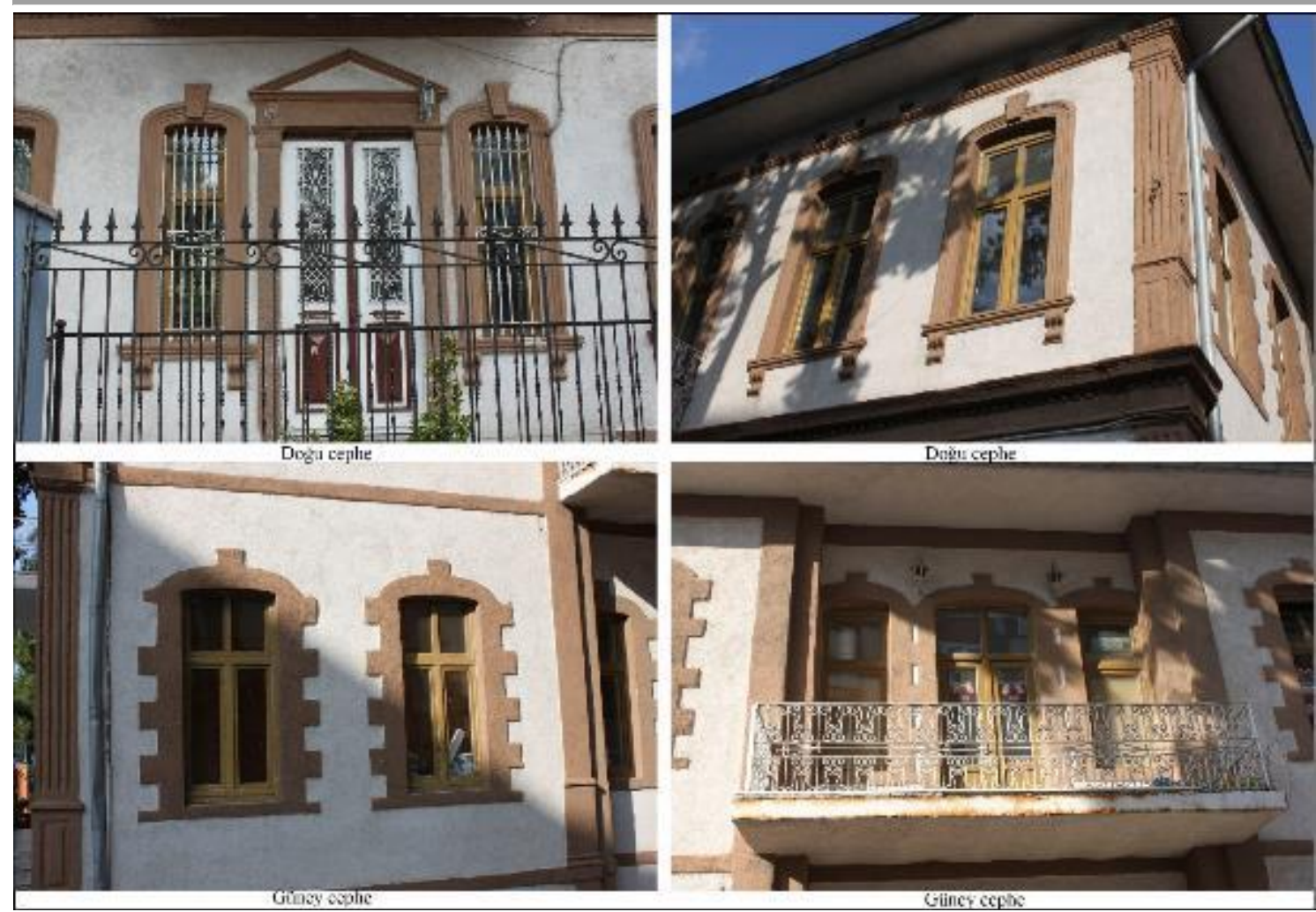

Resim 11: Hasan Rami Paşa Konağ1, cephe detayları. (2019)

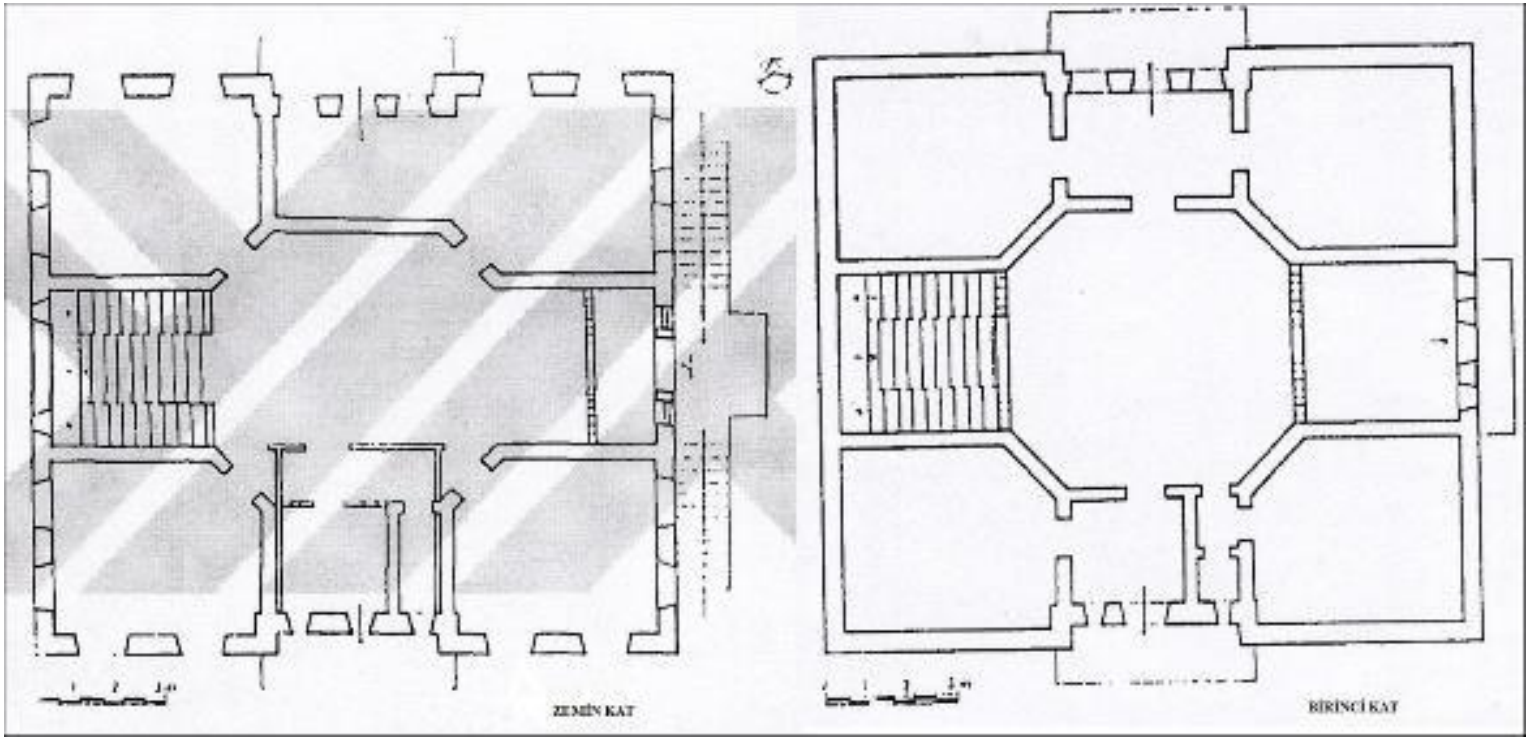

Şekil 3: Hasan Rami Paşa Konağı, orijinal kat planları (N. Tolun). 


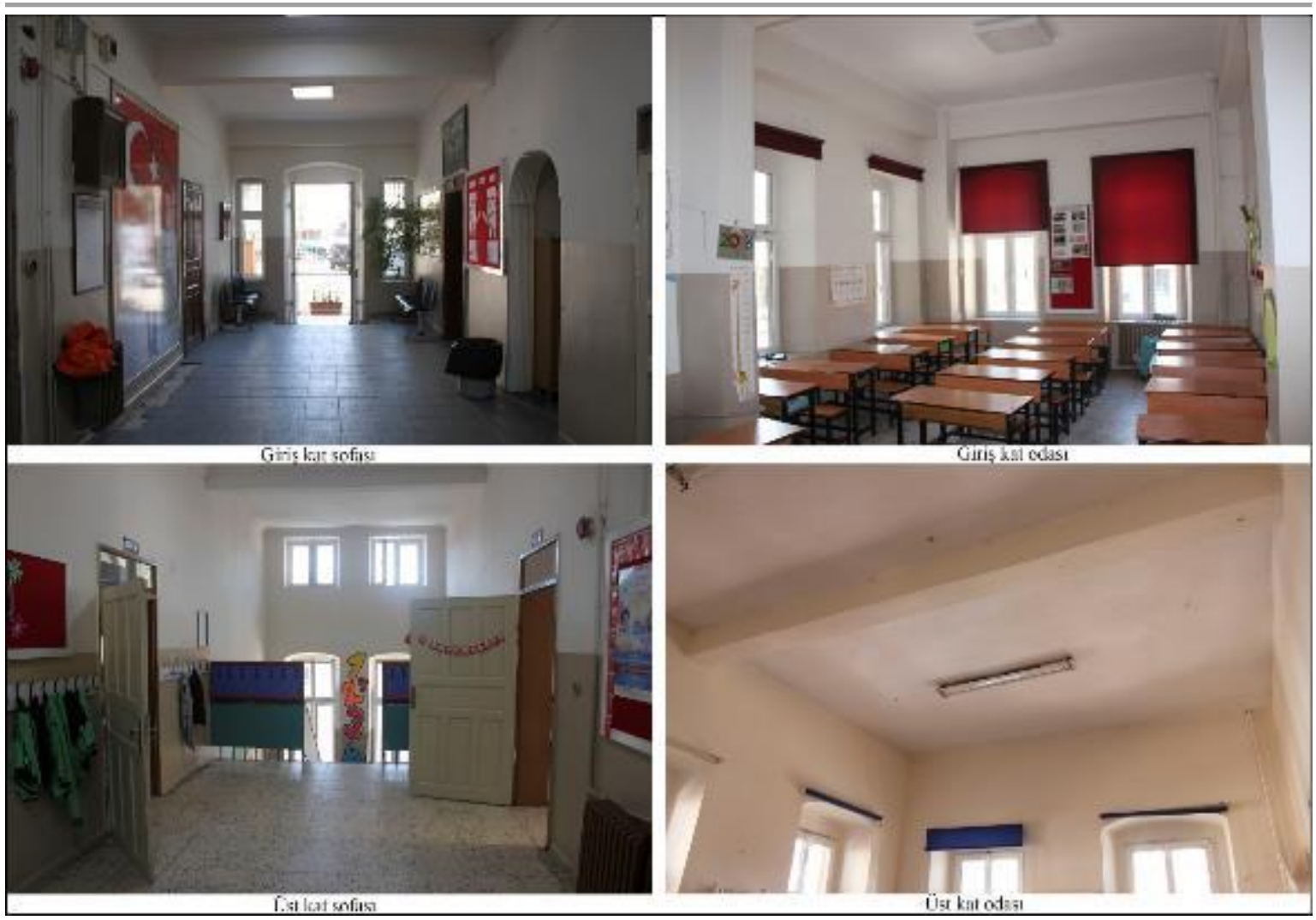

Resim 12: Hasan Rami Paşa Konağı, iç mekân görünümleri. (2018)

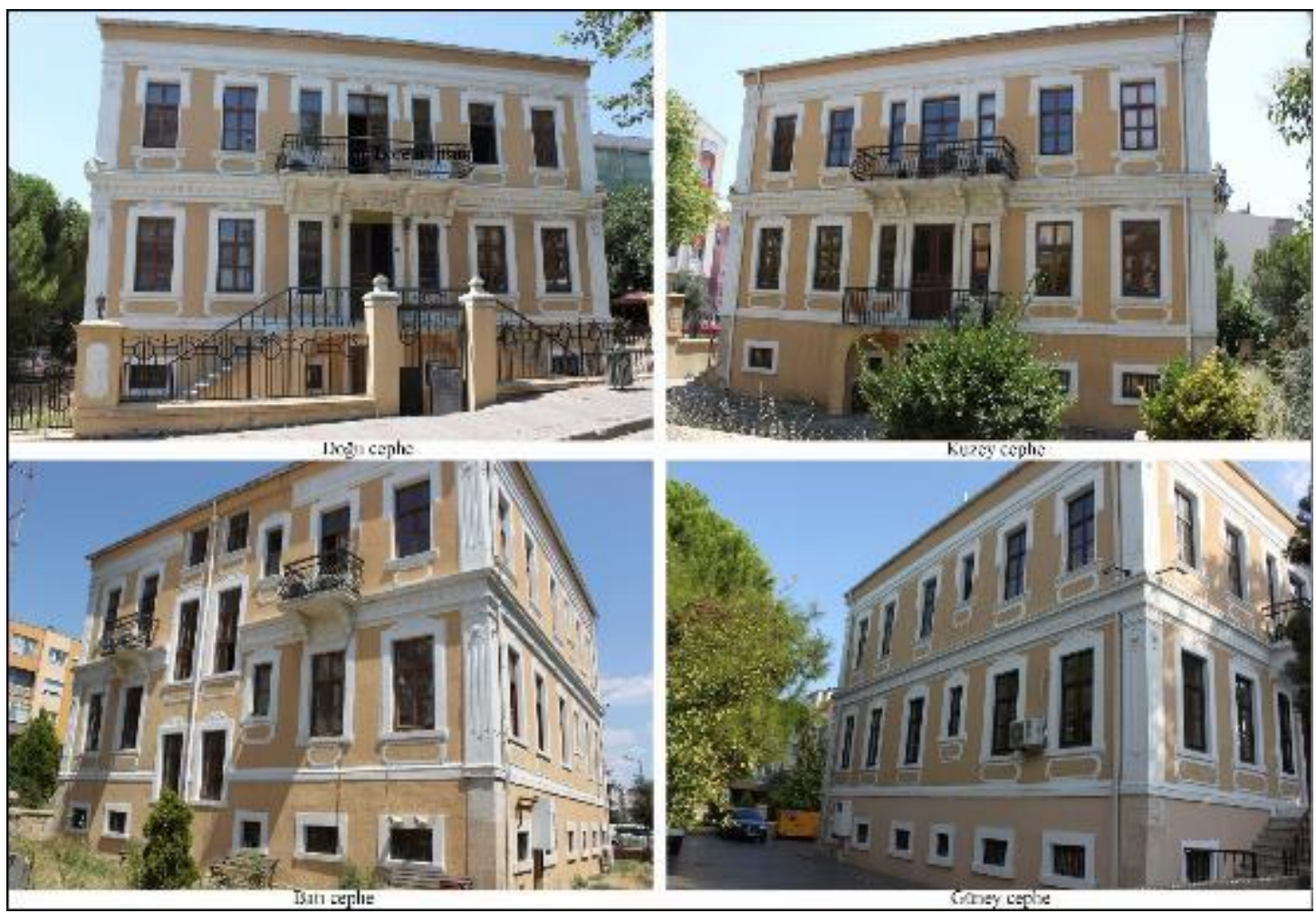

Resim 13: Eski Vali Konağı, cephe görünümleri. (2013) 


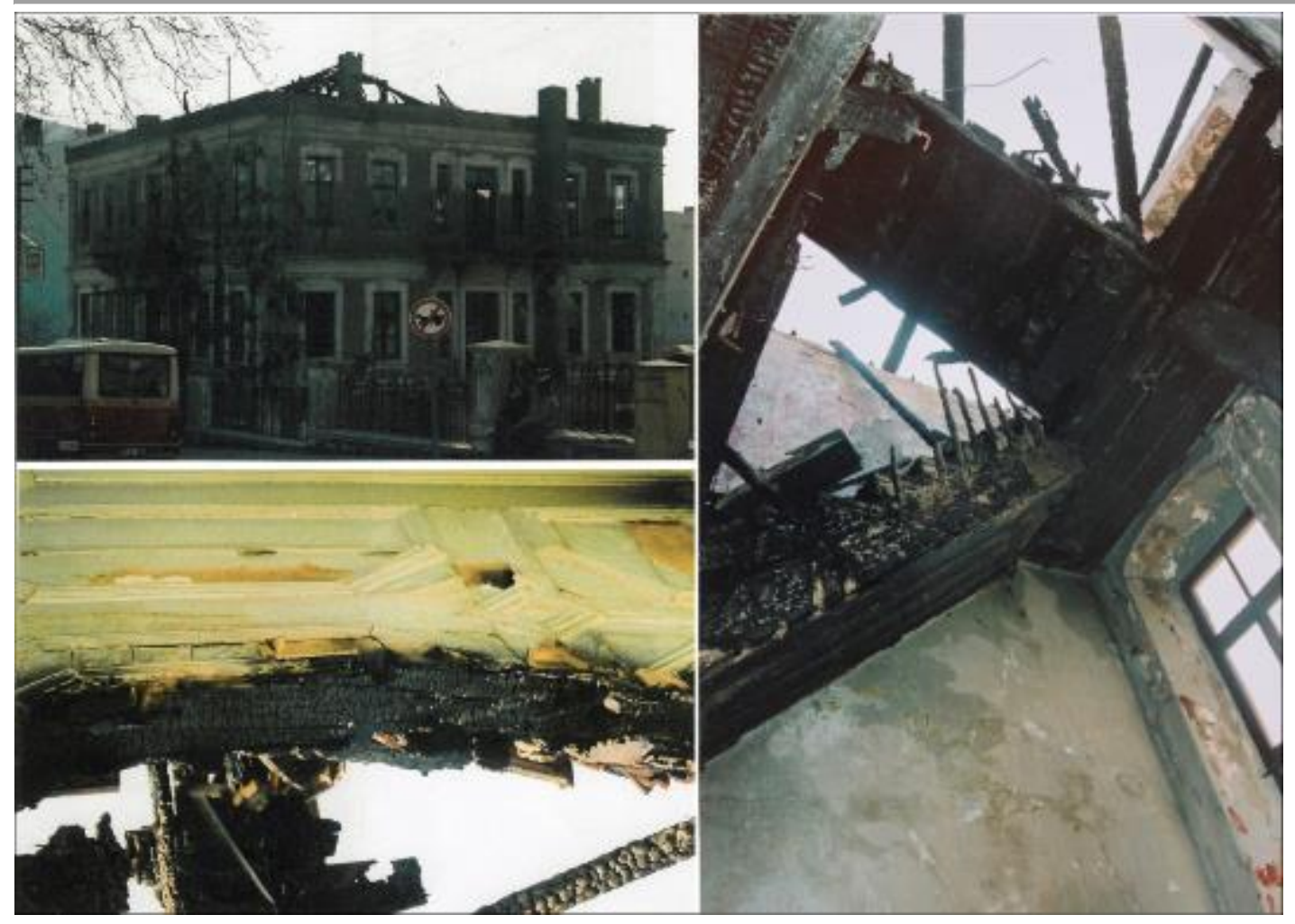

Resim 14: Eski Vali Konağı, yangın sonrası fotoğrafları (ÇKVKBK Arşivi). (2005)

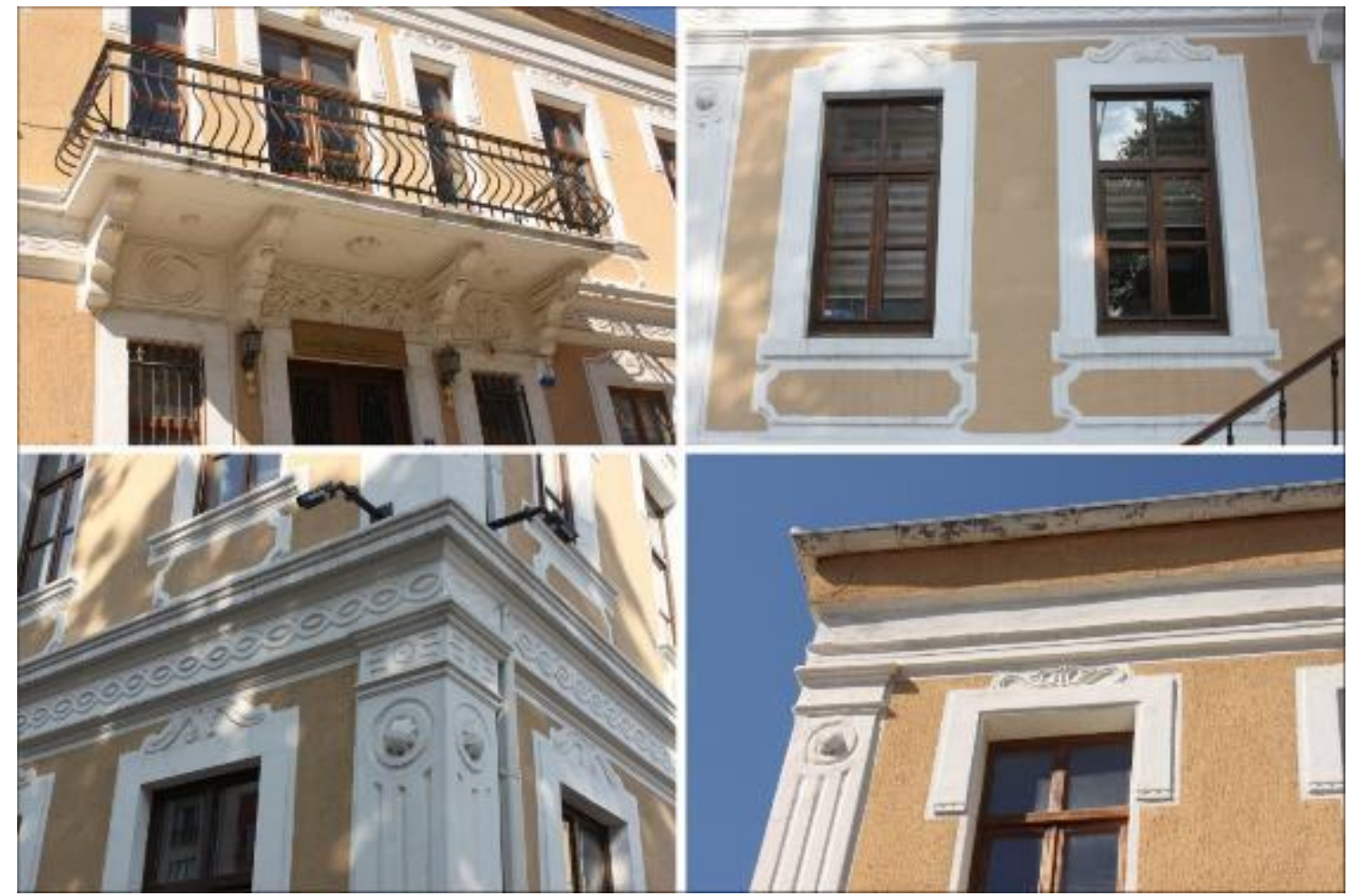

Resim 15: Eski Vali Konağı, ön cephe detayları. (2019) 


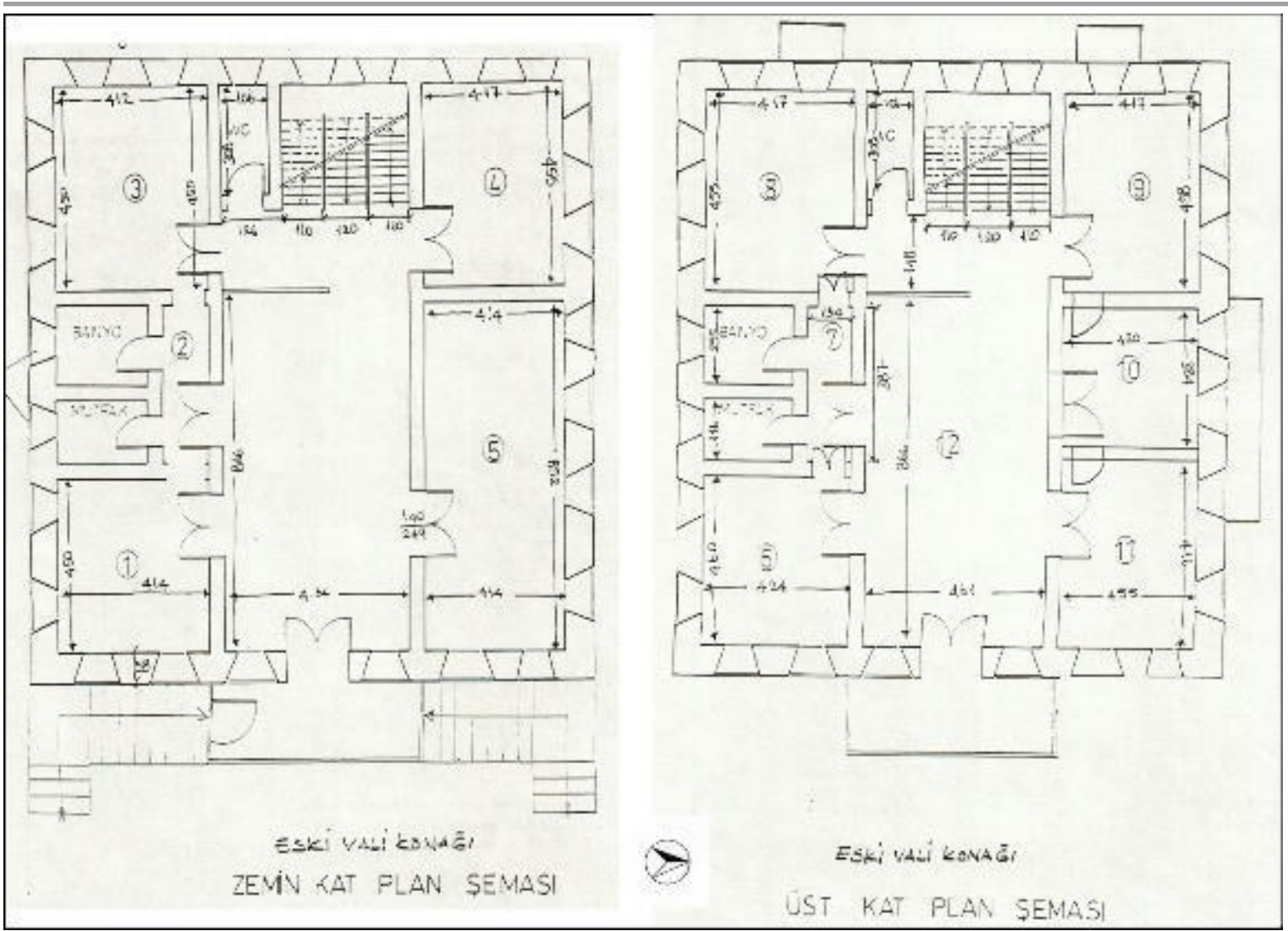

Şekil 4: Eski Vali Konağı, kat planları (ÇKVKBK Arşivi).

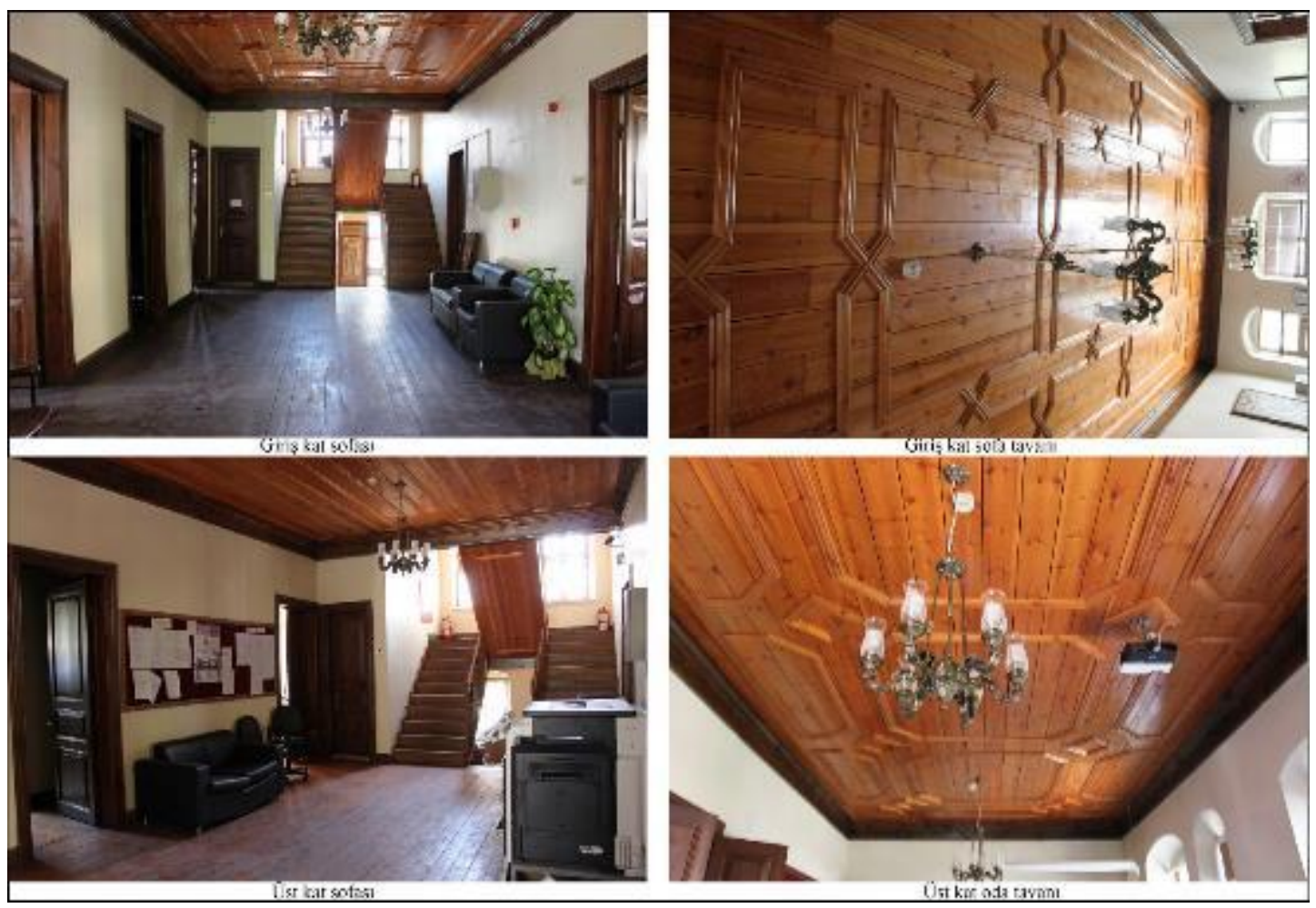

Resim 16: Eski Vali Konağ1, iç mekân görünümleri. (2013) 